\title{
Immunotoxin Therapies for the Treatment of Epidermal Growth Factor Receptor-Dependent Cancers
}

\author{
Nathan Simon and David FitzGerald * \\ Biotherapy Section, Laboratory of Molecular Biology, Center for Cancer Research, National Cancer Institute, \\ National Institutes of Health, 9000 Rockville Pike, 37/5124 Bethesda, MD 20892, USA; nathan.simon@nih.gov \\ * Correspondence: fitzgerd@helix.nih.gov; Tel.: +1-301-496-9457
}

Academic Editor: Tomas Girbes

Received: 5 April 2016; Accepted: 22 April 2016; Published: 4 May 2016

\begin{abstract}
Many epithelial cancers rely on enhanced expression of the epidermal growth factor receptor (EGFR) to drive proliferation and survival pathways. Development of therapeutics to target EGFR signaling has been of high importance, and multiple examples have been approved for human use. However, many of the current small molecule or antibody-based therapeutics are of limited effectiveness due to the inevitable development of resistance and toxicity to normal tissues. Recombinant immunotoxins are therapeutic molecules consisting of an antibody or receptor ligand joined to a protein cytotoxin, combining the specific targeting of a cancer-expressed receptor with the potent cell killing of cytotoxic enzymes. Over the decades, many bacterial- or plant-based immunotoxins have been developed with the goal of targeting the broad range of cancers reliant upon EGFR overexpression. Many examples demonstrate excellent anti-cancer properties in preclinical development, and several EGFR-targeted immunotoxins have progressed to human trials. This review summarizes much of the past and current work in the development of immunotoxins for targeting EGFR-driven cancers.
\end{abstract}

Keywords: immunotoxin; EGFR; cancer therapeutic; clinical development

\section{Introduction}

Cancers have become one of the primary causes of human morbidity and mortality, with worldwide estimates suggesting greater than 20 million new diagnoses annually within the next decade. Progression of many cancers is driven by the genetic alteration or overexpression of specific genes that upregulate signaling pathways involved in proliferation, metastasis, and survival. One group of genes prominently implicated in the development of multiple cancers is the epidermal growth factor receptor (EGFR/HER) genes, a family of four receptor tyrosine kinases (EGFR/HER2/HER3/HER4) involved in a variety of cell signaling pathways (reviewed in [1,2]).

The EGFR proteins consist of an extracellular ligand-binding domain, which binds various ligands including epidermal growth factor (EGF), transforming growth factor alpha (TGF $\alpha$ ), and heparin binding-EGF (HB-EGF), and an intracellular ATP-binding kinase domain (Figure 1). Binding of ligand results in receptor homo- or heterodimerization among EGFR family proteins and activation of the tyrosine kinase domain. Upon activation and dimerization, the kinase domain autophosphorylates the carboxy-terminus of the receptor, allowing binding and activation of downstream signaling partners. These signaling proteins can activate cancer-promoting pathways like cell survival (JAK/STAT), proliferation (MAPK/ERK), angiogenesis (PI3K/AKT), and metastasis (PLC) [3]. EGFR mutations are commonly observed in cancers with both point mutations and large deletions observed in clinical cases. EGFR point mutations are associated with both sensitivity (L858R) and resistance (T790M) to tyrosine kinase inhibitor (TKI) therapies [4,5]. One of the most notable EGFR mutations is the variant III deletion (EGFRvIII) (reviewed in [6]). The deletion of EGFR exons 2-7 results in a protein with a 
truncated extracellular domain that eliminates ligand binding but gains constitutively active kinase activity (Figure 1) [7]. EGFRvIII expression is linked to glioblastoma insensitivity to chemotherapeutic agents through constitutive activation of survival pathways [8,9]. While EGFR activity is crucial to healthy cell functioning, dysregulation of receptor signaling events often leads to aberrant cell growth and development of malignancies.

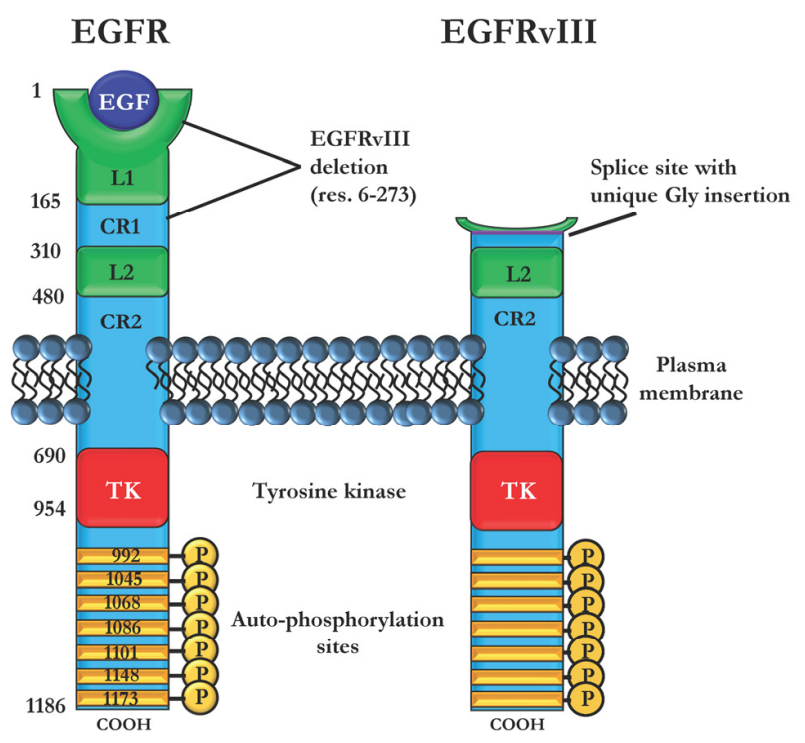

Figure 1. Structure-function organization of the epidermal growth factor receptor (EGFR) and EGFRvIII. EGFR consists of an extracellular ligand-binding region and an intracellular tyrosine kinase region. The extracellular component consists of two ligand binding domains (L1, L2) and two cysteine-rich regions (CR1, CR2) responsible for proper positioning of the ligand binding domains. Upon ligand binding, the receptor assumes an elongated "untethered" conformation and subsequently dimerizes with another EGFR. Upon dimerization, the tyrosine kinase (TK) domain becomes activated and autophosphorylates the receptor. The phosphorylated carboxy terminus becomes a docking site for downstream signaling proteins, which are themselves phosphorylated to promote signaling activation. Mutant EGFRvIII retains the intracellular architecture of EGFR; however, a deletion of residues 6-273 removes much of the ligand binding region. This mutation also results in a constituitively active kinase domain and hyperactive signaling.

Mutation, amplification, or overexpression of the prototype member, EGFR (HER1/ErbB), occurs in breast, lung, bladder, head-and-neck, and pancreatic cancers. More than $60 \%$ of triple-negative breast cancers (TNBC) overexpress EGFR and increased expression strongly correlates with cancer progression and negative outcomes [10]. Ninety-percent of pancreatic cancers, which have a 5 -year survival rate of less than 5\%, display overexpression of EGFR or the EGFR ligands TGF $\alpha$ and EGF [11,12]. Non-small cell lung cancers (NSCLC) and head-and-neck cancers also show overexpression of EGFR and EGFR ligands in more than half of tumor samples [13,14]. Bladder cancers overexpress EGFR, while normal bladder epithelium expresses little or no EGFR [15,16] suggesting that these cancers may too be susceptible to an EGFR-directed therapy. Glioblastomas display EGFR overexpression in greater than $80 \%$ of samples and more than $50 \%$ display additional expression of EGFR deletion variant EGFRvIII $[17,18]$. Other EGFR family members, particularly HER2, have been implicated in colorectal, breast, ovarian, and gastric cancers, but will not be covered here (reviewed in $[2,19])$. Across a multitude of cancer types, enhanced activation and signaling from EGFR receptors correlate with increased cancer aggressiveness and poor patient outcomes (reviewed in [20,21]).

With a wide spectrum of aggressive cancers and minimal therapeutic options, development of effective therapeutics against EGFR-expressing cancers has become a major field of study. A common approach for targeting the EGFR is through monoclonal antibodies targeting EGFR function. Several 
monoclonal antibodies that bind the EGFR extracellular domain and inhibit ligand binding or receptor dimerization have received full clinical approval for human use. Cetuximab (Erbitux $\left.{ }^{\circledR}\right)$ is approved for treatment of colorectal and head-and-neck cancers, and panitumumab (Vectabix $®$ ) is approved for treatment of colorectal cancers [22]. However, newer therapeutics like matuzumab, nimotuzumab, or zalutumumab have shown less promise in clinical trials, and development of several next-generation examples has been discontinued due to little improvement in patient outcomes or adverse patient health effects [23-26]. Additional ligand-neutralizing antibodies targeting TGF $\alpha$ or HB-EGF have demonstrated anti-proliferative activity in vitro and inhibition of tumor growth and high dose-tolerability in vivo [27-29].

A second therapeutic mechanism for targeting EGFR activity is through the use of small molecule tyrosine kinase inhibitors that compete for the kinase active site to inhibit phosphorylation of downstream proteins. Multiple drugs have been clinically-approved, including gefitinib (Iressa ${ }^{\circledR} ;$ NSCLC), lapatinib (Tykerb $®$; breast cancer), and erlotinib (Tarceva ${ }^{\circledR}$; NSCLC and pancreatic cancers) [30-33]. However, patients treated with EGFR TKI invariably develop an EGFR kinase domain T790M "gatekeeper" mutation that blocks inhibitor access, rendering treatment effects only temporary [34]. Second and third generation TKI are being developed in an attempt to circumvent this mutation, and are undergoing human trials [35-38]. Additionally, while cells expressing EGFRvIII may be sensitive to EGFR TKIs, extended treatment results in downregulation of EGFR expression with no accompanying loss of oncogenic growth [39].

One major issue with using anti-EGFR therapeutics in a clinical setting is the potential for off-target effects of the therapeutic. Many healthy tissues have some level of EGFR expression, with the skin, liver, and gastrointestinal tracts expressing elevated levels of the protein. Inhibition of EGFR signaling in these healthy tissues by either anti-EGFR antibodies or TKI result in adverse effects, most commonly skin rash or gastrointestinal disorders. Between $50 \%$ and $100 \%$ of patients treated with anti-EGFR antibodies display various skin rashes, while diarrhea is the most common dose-limiting toxicity in patients treated with EGFR TKI [40]. Therefore, while targeting the activation or signaling of therapeutically-relevant proteins is often able to provide some anti-tumor activity, system-wide inhibition of important signaling pathways is undesirable. Additionally, treatment of the majority of cancers is hampered through therapy-driven genetic mutations or upregulation of alternative signaling pathways, suggesting that a mechanism that does not rely on direct inhibition of cellular signaling pathways would be of great use.

Antibody-cytotoxin fusions, or immunotoxins, have been under development for the treatment of cancers for several decades [41]. Historically, immunotoxins (IT) consist of an antibody or antibody fragment joined to a cytotoxin, typically a bacterial protein like diphtheria toxin (DT) (Figure 2A) or Pseudomonas exotoxin A (PE) (Figure 2B), or a plant-derived ribosomal inactivating protein (RIP) like ricin, gelonin, or saporin (Figure 2C) [42]. Immunotoxins can be engineered through either chemical conjugation of an antibody to the cytotoxin or through recombinant production of a fusion protein, joining an antibody, single chain Fv ( $\mathrm{scFv}$ ), or Fab to a protein toxin. Recombinant ITs most commonly consist of a gene fusion of the $\mathrm{scFv}$ of a relevant cell-targeting domain with the translocation and cell killing domains of DT or PE. As these therapeutics function by killing cells directly rather than through signaling inhibition, the possibility of escape mutation or upregulation of alternative signaling pathways is less of an issue.

DT- and PE-based immunotoxins consist of the translocation and cytotoxic domains of the respective proteins with the toxin's receptor binding domain replaced with the antibody, Fab, or scFv of interest (Figure 2A,B). The cytotoxic activity of DT and PE depends on the catalytic ADP-ribosylation of a unique diphthamide residue on elongation factor 2 (EF2) [43,44], resulting in inhibition of protein synthesis and induction of apoptosis in intoxicated cells [45]. Upon binding to the targeted cellular receptor, immunotoxins enter complex trafficking pathways involving multiple steps (Figure 2D). The targeted receptor is endocytosed and the cytotoxin domain is subsequently released from the targeting domain through furin-like protease activity and intra-chain disulfide 
reduction. Upon endosomal acidification, DT-based toxins are translocated into the cytosol where they find and ADP-ribosylate EF2 [46]. PE-based toxins possess a carboxy-terminal KDEL sequence and enter a retrograde trafficking pathway, passing through the Golgi to the endoplasmic reticulum. Once in the endoplasmic reticulum, the active toxin is translocated to the cytosol through an incompletely understood process and ADP-ribosylates EF2 [47]. EF2 ADP-ribosylation results in an inability to interact with the ribosome, resulting in termination of translation and eventual cell death. The enzymatic nature of these cytotoxins allows for high potency at low toxin concentrations, leading to estimates that delivery of a single molecule is sufficient to cause cell death [48]. Additionally, the limited size of recombinant immunotoxins compared to a full size antibody should allow greatly enhanced tumor penetration, and allow increased access to and killing of interior tumor cells [49].

A.

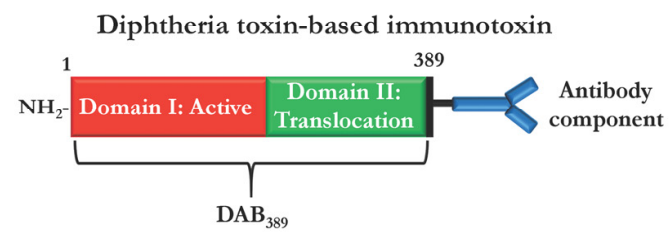

B.

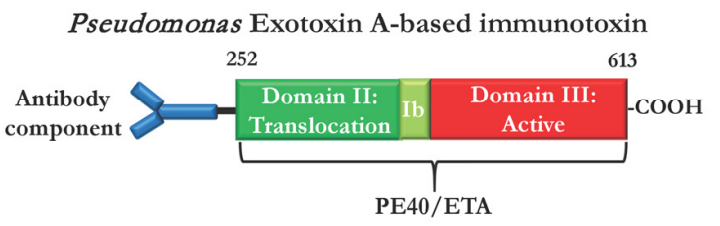

c.

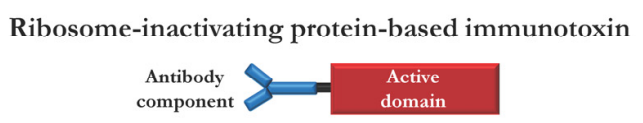

D.

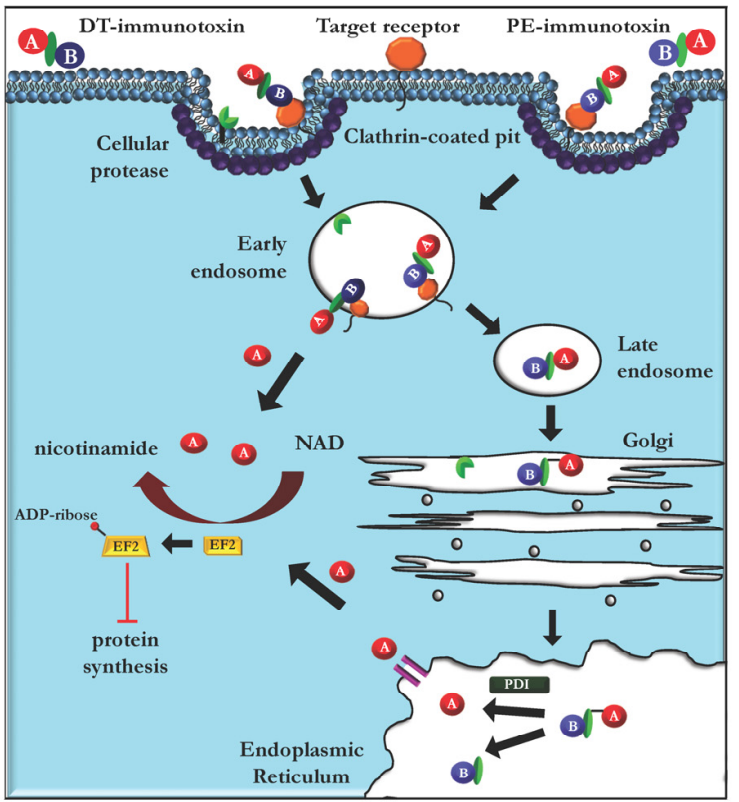

Figure 2. Immunotoxin domain organization and trafficking. (A) Immunotoxins derived from diphtheria toxin (DT) consist of cytotoxic ADP-ribosyltransferase domain I and translocation domain II, with receptor binding domain III replaced by the EGFR-targeting domain of interest. (B) Immunotoxins derived from Pseudomonas exotoxin (PE) are constructed in an inverse manner to DT. PE exotoxins consist of replacement of receptor binding domain I with a new targeting domain joined to the translocation (II) and ADP-ribosyltransferase (III) domains of PE. (C) Immunotoxins utilizing plant-derived ribosome-inactivating proteins (RIP; ricin, saporin, gelonin, dianthin) consist of the RNA glycosidase active domain chemically conjugated to the targeting moeity. (D) Upon endocytosis, immunotoxins enter varied trafficking pathways. Once internalized, cellular proteases cleave the peptide chain between active and translocation domains. DT-based immunotoxins are translocated to the cytosol upon endosomal acidification and disulfide reduction with no other trafficking required. Gelonin, saporin, and dianthin follow a similar pathway, although they do not require protease processing or possess translocation domains. PE-based immunotoxins enter a KDEL-mediated retrograde trafficking pathway, traveling through the Golgi apparatus to the endoplasmic reticulum. In the endoplasmic reticulum, disulfide reduction allows the cytotoxic domain to translocate to the cytosol with the help of ER-resident machinery. Ricin follows a similar pathway.

Plant-derived cytotoxins like gelonin, saporin, and ricin function through a similar end reaction, inhibition of protein synthesis but use a unique catalytic mechanism. After binding to the target receptor and receptor internalization, saporin and gelonin require endosomal disruption to reach the cytosol [50]. Ricin is thought to follow a similar intoxication pathway to PE, trafficking in a retrograde 
fashion through the Golgi to the endoplasmic reticulum before translocation to the cytosol. Interestingly, the pathways may not be identical, as cells resistant to ricin-based immunotoxin are not necessarily resistant to an identical PE-based immunotoxin [51]. Once in the cytosol, RIPs remove a conserved adenosine from the $28 \mathrm{~S}$ ribosomal RNA, blocking further translation and resulting in inhibition of protein synthesis in intoxicated cells. However, ricin has fallen out of favor as a cytotoxic moiety, as human trials with ricin-based immunotoxins show dose-limiting damage to the vasculature [52].

One potential issue with using plant- or bacterial-derived immunotoxins as human therapies is the generation of patient-derived neutralizing antibodies. Clinical trials have demonstrated that $88 \%$ of patients treated with the PE-based SS1P immunotoxin made anti-PE antibodies after one month of treatment [53]. However, additional work has shown that combination of immunotoxin treatment with immunosuppressant regimens reduces the formation of anti-toxin antibodies in mice [54] or humans [55]. Additionally, removal of toxin B-cell [56] and T-cell epitopes [57] has resulted in immunotoxins that do not stimulate development of anti-drug antibodies. These studies indicate that while immunogenicity may be an issue with immunotoxin therapy, it can be overcome with application of appropriate protein engineering and combination therapy strategies.

The ability to combine the specific cell targeting of therapeutic antibodies with the potent cell killing abilities of bacterial or plant proteins has necessarily led to the testing of immunotoxins in various clinical settings. DAB 389 IL2 (denileukin difitox), a fusion of the cytokine IL2 and DT, has been clinically approved for treating cutaneous T-cell lymphoma [58]. Phase I trials have demonstrated that the anti-mesothelin SS1P immunotoxin is well tolerated by human patients, and combination with current front-line chemotherapy has proven effective at treating advanced malignant mesothelioma with an overall response rate of 77\% [53,59]. Additional combination with immunosuppressants further improves patient outcomes [55]. Treatment of patients with relapsed hairy cell leukemia with an anti-CD22 immunotoxin has resulted in durable long-term remissions in patients with the immunotoxin currently in Phase III testing [60]. The potency and adaptability of these therapeutics has led to much work designing an immunotoxin targeting the EGFR for use as a new front-line therapeutic. This review will examine past and recent work in this area, looking at the development of novel EGFR-targeted therapeutics from preclinical investigation (Table 1) to those entered in human trials (Table 2).

Table 1. Pre-clinical development of anti-epidermal growth factor receptor.

\begin{tabular}{|c|c|c|c|c|}
\hline Immunotoxin & Targeting Moiety & $\begin{array}{l}\text { Toxin } \\
\text { Moiety }\end{array}$ & $\begin{array}{c}\text { Susceptible Cancer cell } \\
\text { Types }\end{array}$ & Ref. \\
\hline TGF $\alpha-P E 40$ & TGF $\alpha$; chemical conjugation & PE40 & Epidermoid; prostate & [61] \\
\hline EGF-saporin & EGF; chemical & saporin & Colon, prostate,epithelial & [62] \\
\hline $\operatorname{scFv}(225)-E T A$ & Anti-EGFR MAb225 scFv; fusion protein & PE40 & Breast; epidermoid; oral & [63] \\
\hline 425(scFv)-ETA & Anti-EGFR MAb425 scFv; fusion & PE40 & Pancreatic; RMS & [64] \\
\hline scFv2112-ETA & Cetuximab scFv; fusion & PE40 & Epidermoid; breast; prostate & [65] \\
\hline scFv1711-ETA & Panitumumab scFv; fusion & PE40 & RMS; pancreatic & [65] \\
\hline Cetuximab-saporin & Cetuximab IgG; chemical & saporin & - & [66] \\
\hline Cetuximab-dianthin & Cetuximab IgG; chemical & dianthin & - & [67] \\
\hline Panitumumab-dianthin & Panitumumab IgG; chemical & dianthin & - & [67] \\
\hline L8A4-PE35 & Anti-EGFRvIII L8A4 IgG; chemical & PE35 & EGFRvIII-transfected N6M & {$[68]$} \\
\hline MR1(Fv)-PE38 & Anti-EGFRvIII MR1 scFv; fusion & PE38 & Glioblastoma & [69] \\
\hline 806-PE38 & Anti-EGFR/EGFRvIII MAb806 scFv; fusion & PE38 & $\begin{array}{c}\text { TNBC; NSCLC; Epidermoid } \\
\text { Head-and-neck; }\end{array}$ & [70] \\
\hline DT390-BiscFv806 & Anti-EGFR/EGFRvIII MAb806 scFv; fusion & $\mathrm{DT}_{390}$ & $\begin{array}{l}\text { EGFRvIII-transfected } \\
\text { U87MG }\end{array}$ & {$[71]$} \\
\hline scFv(14E1)-ETA & $\begin{array}{l}\text { Anti-EGFR/EGFRvIII MAb14E1 } \\
\text { scFv; fusion }\end{array}$ & PE40 & Glioblastoma; breast; renal & {$[72]$} \\
\hline
\end{tabular}

Abbreviations: TGF $\alpha$ : Transforming growth factor alpha; EGF: Epidermal growth factor; EGFR: Epidermal growth factor receptor; RMS: rhabdomyosarcoma; TNBC: Triple-negative breast cancer; NSCLC: Non-small cell lung cancer; PE40: Domains II (translocation), Ib, and III (cytotoxic) of Pseudomonas exotoxin; $\mathrm{DT}_{390}$ : Domains I (cytotoxic) and II (translocation) of diphtheria toxin; PE38: Domains II (translocation) and III (cytotoxic) of Pseudomonas exotoxin. 
Table 2. Clinical development of anti-epidermal growth factor receptor immunotoxins.

\begin{tabular}{|c|c|c|c|c|c|}
\hline Immunotoxin & Targeting Moiety & $\begin{array}{l}\text { Toxin } \\
\text { Moiety }\end{array}$ & $\begin{array}{c}\text { Clinical Trials: } \\
\text { Indicated Cancer(s) }\end{array}$ & $\begin{array}{l}\text { Clinical Trial } \\
\text { Status }\end{array}$ & Ref. \\
\hline TP38 & $\begin{array}{l}\text { TGF } \alpha \text {; chemical } \\
\text { conjugation }\end{array}$ & PE38 & Malignant brain tumors & $\begin{array}{c}\text { Phase I; } \\
\text { discontinued }\end{array}$ & {$[73,74]$} \\
\hline $\mathrm{DAB}_{389}$-EGF & EGF; chemical & $\mathrm{DT}_{389}$ & $\begin{array}{c}\text { Solid tumors with EGFR } \\
\text { overexpression }\end{array}$ & $\begin{array}{l}\text { Phase I/II; } \\
\text { discontinued }\end{array}$ & [75] \\
\hline MR1-1(Fv)-PE38 & $\begin{array}{l}\text { Anti-EGFRvIII MR1 } \\
\text { scFv; fusion protein }\end{array}$ & PE38 & Malignant brain tumors & $\begin{array}{c}\text { Phase I; } \\
\text { discontinued }\end{array}$ & [76] \\
\hline D2C7(scdsFv)-PE38 & $\begin{array}{l}\text { Anti-EGFR/EGFRvIII } \\
\text { MAbD2C7 scFv; fusion }\end{array}$ & PE38 & Malignant glioma & Phase I/II & [77] \\
\hline
\end{tabular}

Abbreviations: Transforming growth factor alpha: TGF $\alpha$; Epidermal growth factor: EGF; Epidermal growth factor receptor: EGFR; DT 389 : Domains I (cytotoxic) and II (translocation) of diphtheria toxin; PE38: Domains II (translocation) and III (cytotoxic) of Pseudomonas exotoxin.

\section{Literature}

\subsection{Ligand Immunotoxins}

EGFR, like other receptor tyrosine kinases, is activated through the binding of various extracellular ligands like TGF $\alpha$ and EGF. While antibodies targeting a cell surface receptor are the most common binding components of immunotoxins, the use of receptor ligands as the targeting moiety of the molecule has also been explored. Ligand binding to EGFR results in receptor dimerization and endocytic uptake, where the immunotoxin then follows defined trafficking pathways to the cytosol to exert toxic effects [78]. Initial ligand-immunotoxin work focused on targeting the EGFR with a fusion of TGF $\alpha$ with a $40 \mathrm{kDa}$ fragment of PE consisting of the translocation and cytotoxic domains (TGF $\alpha$-PE40/TP40) (Figure 3A) [61]. This molecule was tested on epidermoid and prostate cancer cells known to express amplification of EGFR, and proved to be highly active in vitro with $\mathrm{IC}_{50}$ (inhibitory concentration: $50 \%$ inhibition) lower than $1 \mathrm{ng} / \mathrm{ml}$ and doubling the mouse survival time in murine xenograft models $[79,80]$. Later protein engineering led to TGF $\alpha$ immunotoxins with truncated PE domains of 38,35 and $31 \mathrm{kDa}$, which were more potent than the parental TGF $\alpha$-PE40 [81-83].

Bladder cancers rely upon TGF $\alpha$ as the primary EGFR ligand [86], suggesting that therapeutics utilizing TGF $\alpha$ as a targeting agent would be beneficial for treatment of these malignancies. Preclinical studies demonstrated that TGF $\alpha$-immunotoxins are highly cytotoxic to bladder cancer cells and patient bladder cancer explants, despite the lack of EGFR amplification in these cells [87,88]. Transition of this molecule to Phase I clinical trials showed that TP40 is well tolerated in patients with superficial bladder cancer with no dose limiting toxicities noted [89]. Eight of nine patients with carcinoma in situ demonstrated partial or complete responses to treatment. Patients with invasive disease showed no response to treatment and no visible changes in tumors observed; however, this observation may be due to the therapeutic being delivered directly into the urinary bladder, while a systemic administration would potentially allow better treatment distribution. TP38, a similar molecule with TGF $\alpha$ linked to a $38 \mathrm{kDa}$ fragment of PE, was tested in Phase I trials of malignant brain tumors with intracranial infusion techniques utilized for treatment delivery directly to tumor tissue [73,74]. Two of fifteen patients demonstrated radiographic responses to treatment with survivals of greater than 200 weeks post-treatment. However, two dose limiting neurologic toxicities were noted, including grade 3 hemiparesis and grade 4 fatigue. Additionally, the observation that $>80 \%$ of infusions resulted in treatment leakage to other areas of the brain suggests that intracranial infusions may be less effective in practice. 
A.

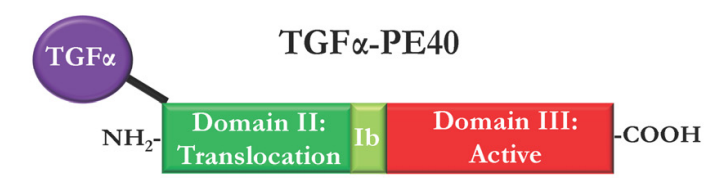

B.

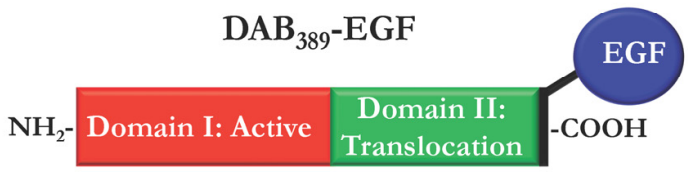

C.

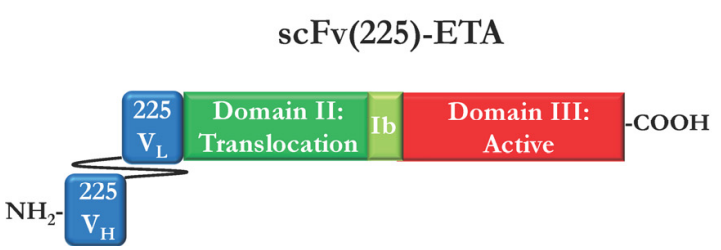

D.

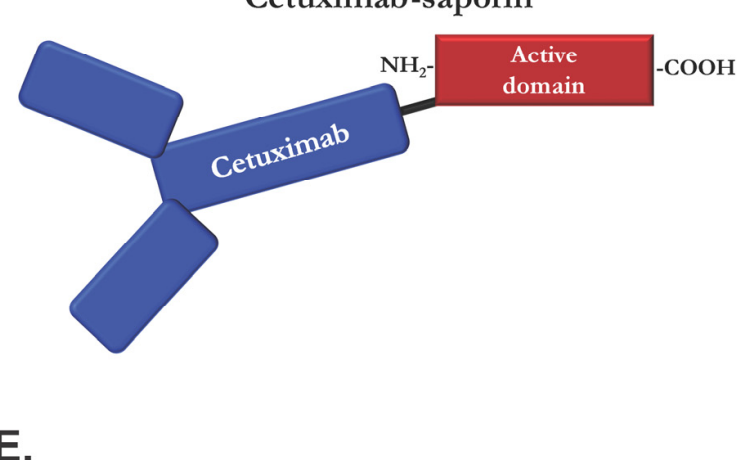

D2C7(scdsFv)-PE38

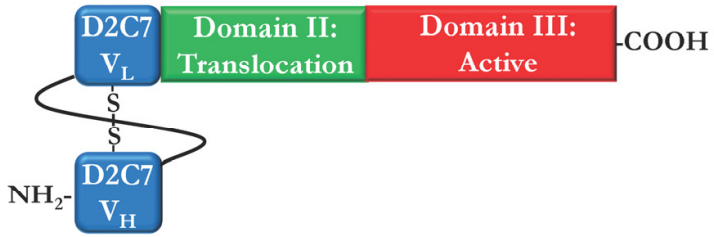

Figure 3. Anti-epidermal growth factor receptor immunotoxins possess considerable variability in domain organization and targeting moieties. (A) Transforming growth factor $\alpha$-PE40 is the prototype anti-EGFR immunotoxin and an example of a ligand-immunotoxin [61]. TGF $\alpha$-PE40 utilizes the EGFR ligand TGF $\alpha$ as a targeting component and domains II, Ib, and III of Pseudomonas Exotoxin A (PE) as the cytotoxin component. (B) DAB389-EGF functions similarly to TGF $\alpha$-PE40 but uses epidermal growth factor (EGF) for the receptor ligand and swaps PE for a diphtheria toxin (DT)-based cytotoxin component [84]. (C) The majority of recent EGFR-targeted immunotoxins utilize a single chain Fv (scFv) from an anti-EGFR monoclonal antibody. A prototype molecule, $\mathrm{scFv}(225)-\mathrm{ETA}$, consists of the variable heavy $\left(\mathrm{V}_{\mathrm{H}}\right)$ and light $\left(\mathrm{V}_{\mathrm{L}}\right)$ chains of the monoclonal 225 antibody joined by a flexible peptide linker and fused to the PE40 cytotoxin derivative [63]. (D) Full-length IgG have been chemically conjugated to cytotoxins, as in the case of cetuximab-saporin [66]. These molecules retain bivalent binding, but their large size has led to questions about tumor penetration ability. (E) D2C7(scdsFv)-PE38 consists of the scFv of an antibody capable of binding both wild type EGFR and deletion mutant EGFRvIII [85]. Use of scFv allows for a smaller molecule, but the flexibility of the connection can result in loss of stability or binding. The introduction of an intra-chain disulfide linking $\mathrm{V}_{\mathrm{H}}$ and $\mathrm{V}_{\mathrm{L}}$ increases receptor affinity and immunotoxin stability.

EGF-based immunotoxins have also received research attention. Initial development of a fusion of EGF to the catalytic domain of DT resulted in a protein that was non-toxic to EGFR-expressing cells in vitro [90]. Subsequent protein engineering confirmed that domain II, the "translocation domain", of diphtheria toxin is required for endosome escape and cytotoxicity. A fusion of EGF and the catalytic and translocation domains of DT (DAB ${ }_{389} \mathrm{EGF}$ ) (Figure 3B) killed multiple human cancers at pM concentrations [84]. Similar to TGF $\alpha-P E 40, D^{-1} B_{389} E G F$ has been investigated for the treatment of bladder cancers, demonstrating potent killing of bladder cancer cells in vitro and elimination of tumor burden in five of six mice in vivo [91]. This molecule has undergone additional preclinical investigation for treatment of brain cancers with amplification or overexpression of EGFR, showing cell killing abilities at pM concentrations against a panel of human glioblastoma cell lines [92]. In mice, $\mathrm{DAB}_{389} \mathrm{EGF}$ has a dose-limiting toxicity of renal failure at doses of $5 \mu \mathrm{g} / \mathrm{mouse}$; however, $75 \%$ of mice implanted with glioblastoma and subsequently treated with $3 \mu \mathrm{g} \mathrm{DAB}_{389} \mathrm{EGF} / \mathrm{mouse}$ showed tumor regression and were in remission at 60 days post-treatment [93]. Intracranial delivery of EGF-DT is also efficacious in a murine model of NSCLC brain metastasis, increasing survival time by $28 \%$ [94]. 
A Phase I/II clinical trial of $\mathrm{DAB}_{389}$ EGF for treatment of solid tumors with EGFR expression enrolled fifty-two patients with metastatic disease who were treated with increasing doses of $\mathrm{DAB}_{389} \mathrm{EGF}$ [75]. One patient (NSCLC) displayed a partial response, and three others showed stable disease through the duration of the trial. However, all patients developed anti-DT or anti-EGF neutralizing antibodies, and dose-limiting toxicities due to liver or kidney damage and chest pain were observed. EGF or HB-EGF have also been conjugated to other toxin fragments, with EGF-PE [95], EGF-ricin [90], EGF-saporin [62], and HBEGF-saporin [96,97] also showing specific toxicity to EGFR-expressing cancers in vitro or in vivo while remaining mostly non-toxic to healthy cells. However, the lack of sustained clinical responses coupled with patient-generated neutralizing antibodies has hindered further clinical development of EGFR-ligand immunotoxins.

\subsection{Immunotoxins Based on Monoclonal EGFR Antibodies}

EGFR-ligand immunotoxins are potent anti-EGFR therapeutics in a preclinical research setting, but have proven less successful in clinical trials due to dose-limiting toxicities and poor response rates. Many current anti-cancer therapeutics are based on monoclonal antibodies, which allow for greater targeting specificity and improved potency through protein engineering techniques [98]. Anti-EGFR antibodies have been under investigation for treatment of various EGFR-expressing cancers for several decades, with varying degrees of success [99-102]. Many researchers have taken advantage of the high affinity of these monoclonal antibodies for EGFR to build anti-EGFR immunotoxins, with the goal of delivering low levels of toxin to cells overexpressing the EGFR while sparing cells with low or normal levels of the protein. Most commonly, the scFv of the antibody is used as the binding component (Figure 3C), to retain much of the antibody's affinity while rendering the therapeutic much smaller for better tumor penetration. However, antibody Fab or even entire antibody IgG have been used as EGFR targeting moieties (Figure 3D).

The mouse monoclonal antibody (MAb) 225 was identified in 1983 as a potent inhibitor of EGF binding to EGFR, resulting in a significant decrease in proliferation of A431 epidermoid carcinoma cells displaying EGFR amplification [103]. MAb225 not only inhibited ligand binding, but also promoted receptor internalization in the absence of receptor activation [104], suggesting it could be an ideal candidate for immunotoxin delivery. An immunotoxin constructed from the scFv of MAb225 fused to domains II and III of PE (scFv(225)-ETA) (Figure 3C) proved strongly cytotoxic to breast and epidermal cancer cells with amplified EGFR [63]. scFv(225)-ETA inhibited EGFR activation in the presence of EGF, suggesting that this immunotoxin can inhibit EGFR activity either by interrupting signaling or through cytotoxic activity. scFv(225)-ETA exhibited cytotoxicity towards cells with even moderate EGFR expression, but showed no toxicity towards cells with no EGFR expression [105]. Treatment of CAL27 squamous cell xenografts with $\mathrm{scFv}$ (225)-ETA resulted in significant tumor growth suppression, although no complete regressions were noted for this treatment.

Another early antibody was identified to strongly bind the EGFR was the monoclonal anti-EGFR 425 antibody (MAb425) [106]. MAb425 binds an epitope distinct from that bound by MAb225/cetuximab [107], but still possesses anti-tumor activity in vivo [108]. The MAb425 scFv has been engineered into an immunotoxin, $425(\mathrm{scFv})$-ETA, comprised of the MAb425 scFv fused to the $40 \mathrm{kDa}$ fragment of PE consisting of the translocation and cytotoxic domains (PE40/ETA). $425(\mathrm{scFv})-\mathrm{ETA}$ was strongly cytotoxic towards metastatic pancreatic cancer cells with an $\mathrm{IC}_{50}$ of less than $10 \mathrm{ng} / \mathrm{mL}$ [64], while EGFR-negative cells were unaffected at concentrations of immunotoxin lower than $10 \mu \mathrm{g} / \mathrm{mL}$. 425(scFv)-ETA was also highly effective against pancreatic tumors metastases in vivo. In mice injected with metastatic pancreatic cells, multiple injections of $425(\mathrm{scFv})$-ETA reduced the number of lung metastases from 56 per mouse to 0.28 per mouse, suggesting that immunotoxins may be effective at targeting not only primary tumors but also secondary tumor spread [109]. Furthermore, 425(scFv)-ETA bound ex vivo tissue from patients with rhabdomyosarcoma, an aggressive cancer most common in children, and killed rhabdomyosarcoma cells with pM potency in vitro [110]. MAb425 has been humanized (matuzumab), but Phase II human trials did not result in significantly 
improved outcomes [25] and development has been halted, suggesting that $425(\mathrm{scFv})$-ETA may not be an ideal candidate for further development.

While immunotoxins derived from mouse antibodies possess considerable preclinical activity, further development would require antibody humanization and human safety profiling. Taking advantage of molecules with established safety profiles, several groups have investigated the use of antibodies already clinically approved as targeting moieties. Anti-EGFR antibodies approved for use in treating human cancers include cetuximab, approved for colorectal and head-and-neck cancers, and panitumumab, approved for colorectal cancers. Cetuximab is a human-mouse chimeric protein consisting of the mouse MAb225 variable region and a humanized constant region and has 10-fold higher affinity for EGFR than the parental MAb225 [111]. While panitumumab is a fully humanized antibody [112], both antibodies bind a similar epitope on the EGFR extracellular domain and function through inhibition of ligand binding [113]. With knowledge that the targeting domains are safe for human use, ITs utilizing the full-length antibody or antibody fragments of cetuximab or panitumumab have received increasing attention in preclinical studies.

The immunotoxins scFv2112-ETA and scFv1711-ETA are composed of the scFv of cetuximab and panitumumab, respectively, joined to domains II and III of PE (PE40/ETA) [65]. These immunotoxins were tested in vitro and ex vivo against a panel of cancer types known to rely on EGFR signaling, including breast, epidermoid, pancreatic, and prostate cancers. Both immunotoxins demonstrated strong induction of apoptosis and potent cell killing toward representative cell lines with a range of EGFR expression from 149,000 receptors/cell to 12,500 receptors/cell. Interestingly, scFv2112-ETA was more toxic to epidermoid, breast, and prostate cancers, while scFv1711-ETA was more toxic to rhabdomyosarcoma and pancreatic cancers. Cytotoxic potency ranged from 4-460 pM and correlated with EGFR expression. EGFR-null cells were unaffected, confirming the specificity of these immunotoxins toward EGFR-expressing cancers. Notably, both immunotoxins stimulated apoptosis in a greater percentage of cells than cetuximab or panitumumab alone. Ex vivo studies demonstrated strong binding of both constructs to tissue samples obtained from patients with breast, prostate, and rhabdomyosarcoma cancers. With their safety in humans already established, the use of previously approved antibodies for IT construction could be more effective and less immunogenic in clinical cancer treatment.

One property of monoclonal antibody therapeutics that most immunotoxins do not possess is the induction of antibody-dependent cell-mediated cytotoxicity (ADCC), which relies on the Fc component of the antibody being recognized by natural killer (NK) cells. Upon Fc binding, the NK cells become activated and stimulate killing of antibody-bound tumor cells [114,115]. Preservation of this additional cell killing modality in immunotoxin treatment has been attempted through the use of the full length cetuximab IgG as an immunotoxin targeting component [66]. The full-length cetuximab IgG was covalently conjugated to the plant ribosome-inactivating protein saporin, creating the cetuximab-saporin immunotoxin (Figure 3D). On its own, cetuximab-saporin possesses low cytotoxicity, with $10 \mathrm{nM}$ concentrations failing to kill cells. However, the addition of saponins, plant-derived chemicals which specifically create pores in endosomes/lysosomes [116], increases immunotoxin potency by up to 1000-fold with no effects on non-target cells [117]. Upon addition of the saponin SO1861, cetuximab-saporin demonstrated complete cell killing at a $10 \mathrm{nM}$ concentration, suggesting that an inability of the saporin to access the cytosol was to blame for the poor cytotoxicity [66]. In addition to the saporin cytotoxic activity, retention of the Fc of the full cetuximab antibody stimulated NK-cell dependent ADCC, enhancing the cell killing potential of cetuximab-saporin.

Similar results have been reported for panitumumab-dianthin and cetuximab-dianthin immunotoxins. Dianthin is another plant-derived ribosome-inactivating protein, cleaving an adenosine from ribosomal RNA to prevent protein synthesis [118]. Dianthin-panitumumab and dianthin-cetuximab immunotoxins engineered from the full length therapeutic IgG conjugated to recombinant dianthin similarly showed no killing of EGFR-overexpressing colorectal cancer cells when administered at concentrations below $10 \mathrm{nM}$ [67]. Addition of the SO1861 saponin significantly 
increased the cytotoxicity of these immunotoxins with $\mathrm{IC}_{50}$ values of $1.5 \mathrm{pM}$ (dianthin-panitumumab) and $5.3 \mathrm{pM}$ (dianthin-cetuximab).

The potency and non-bacterial origin of IgG-RIP immunotoxins suggests that they may be suitable for further clinical development. To date, no in vivo results have been reported for cetuximab or panitumumab-based immunotoxins; however, two potential issues may limit the potency of these constructs in vivo. The lack of an efficient cellular trafficking pathway for these toxins, with requirement for endosome/lysosome disruption by saponins, may not allow the therapeutics to reach peak toxicity. The size of full IgG immunotoxins, more than $200 \mathrm{kDa}$, may hamper the ability to sufficiently penetrate into solid tumors resulting in poorer treatment [49]. Further experiments in vivo should shed more light on the therapeutic potential of these RIP-based immunotoxins.

\subsection{Immunotoxins Targeting Cancers Expressing Mutant EGFRvIII}

Immunotoxins targeting wild type EGFR may be ideal for treating cancers with EGFR amplification or overexpression, but some EGFR-driven cancers rely upon expression of EGFRvIII, a truncated form of EGFR. EGFRvIII is a splice variant in which a mutation causing exons 2-7 to be removed results in a deletion of 801 DNA base pairs corresponding to residues 6-273 of the extracellular domain of the protein (Figure 1). This in-frame deletion also results in the creation of a unique glycine residue and unique peptide sequence at the splice site [119]. The loss of a portion of the extracellular protein renders EGFRvIII incapable of binding ligands. Instead, EGFRvIII gains constitutive kinase activity, resulting in hyperactivation of EGFR signaling and enhanced proliferation and survival over cancers with EGFR alone [120,121]. EGFRvIII is not expressed in healthy tissues, indicating that it is a cancer-specific marker and making it an ideal therapeutic target. EGFRvIII is most commonly noted in glioblastoma $(40 \%-60 \%)[17,122]$ and is detected rarely in lung cancers [123], head-and-neck cancers [124] or breast cancers [125]. In glioblastoma, which has five-year survival rates of less than 5\% [126], EGFRvIII may be used as a prognostic factor as expression is significantly correlated with poor survival rates [127]. As treatment modalities for glioblastoma are currently limited to chemotherapy and radiation, the targeting of EGFRvIII with immunotoxins has received much attention.

One challenge to creating an EGFRvIII-targeted immunotoxin is creating a binding fragment that will not have off-target reactivity with wild type EGFR on healthy cells. One approach that has proven successful in generating anti-EGFRvIII antibodies is the use of phage-display libraries. The L8A4 antibody, which targets the unique peptide formed by insertion of the novel glycine residue at the mutation splice site, was isolated from one such library [17]. A PE-based immunotoxin attached to the full-length L8A4 IgG was tested on EGFR-null N6M cells expressing EGFRvIII cDNA. As EGFRvIII is not maintained by cells in culture, much of the pre-clinical work on this protein required transient or stable expression of the protein from a plasmid [128]. L8A4-PE35 is cytotoxic to cells expressing EGFRvIII at pM concentrations, but only weakly toxic to cells overexpressing wild type EGFR [68]. However, therapeutics with large molecular weights have significantly worse tumor penetration than smaller molecules, so development of a similar immunotoxin with a smaller binding domain was desired for further work [49].

To identify an antibody fragment with similar binding specificity to L8A4, the unique peptide formed by the EGFRvIII splice variant was used as an antigen to generate a library of phage displaying murine $\mathrm{scFv}$ [69]. The scFv MR1 was isolated from this screen and was fused to the PE38 exotoxin to create MR1(Fv)-PE38 for treatment of glioblastoma expressing EGFRvIII. MR1(Fv)-PE38 was effective at killing glioblastoma cells both in vitro and in vivo. In a rat model of glioblastoma, MR1(Fv)-PE38 immunotoxin treatment extended animal median survival to $>53$ days, compared to control animal survival of merely seven days [129]. Improvements to the binding affinity of MR1 were made through targeted mutagenesis of the complementary determining region-3 of the heavy and light chains of the scFv [130]. The resulting MR1-1 possesses 15-fold higher affinity for EGFRvIII, demonstrating the 
strength of antibody affinity maturation [131]. MR1-1(Fv)-PE38 displayed 3.5-fold increased potency toward cells expressing EGFRvIII compared to the parental MR1(Fv)-PE38 [130].

An issue with treating diseases of the brain is delivering large molecular weight therapeutics across the blood-brain barrier. One technique developed to circumvent this issue is convection enhanced delivery (CED), in which a drug is delivered directly to the brain tissue through a catheter and circulated throughout with the use of pressure gradients [132]. As immunotoxins are large therapeutics, a pilot safety study utilizing CED to deliver MR1-1(Fv)-PE38 directly to tumor tissue was performed in rats [133]. All animals survived the treatment with no signs of neurotoxicity or other adverse effects noticed. MR1-1(Fv)-PE38 entered Phase I trials for safety profiling in treatment of malignant brain tumors; however, this trial has since been terminated due to low accrual [76]. Given the poor prognosis for current glioblastoma treatments, targeting EGFRvIII with immunotoxin therapy may be a viable alternative, although additional clinical work to determine ideal combination therapies and treatment approaches is necessary.

\subsection{Bispecific and Conformation-Dependent Immunotoxins}

Protein engineering techniques allowing for engineering of antibodies with specific properties have led to the "designing" of antibodies with the ability to target specific epitopes of a target protein. Utilizing the extracellular region common to both truncated EGFRvIII and wild type EGFR as an antigen, antibodies that can bind both EGFRvIII and wild-type EGFR are being used as the basis of bi-specific immunotoxins to target diverse cancers with either EGFR amplification or EGFRvIII expression. One example, the D2C7 antibody, was generated by immunizing mice with a peptide corresponding to the junction created by the EGFRvIII mutation [85]. D2C7 binds both EGFRvIII and EGFR and possesses the ability to bind malignant tissue that either overexpresses EGFR or expresses EGFRvIII. As glioblastomas often both overexpress EGFR and express EGFRvIII, this binding specificity has led to $\mathrm{D} 2 \mathrm{C} 7$ being utilized as the basis of an immunotoxin currently being investigated for the treatment of these cancers. D2C7(scdsFv)-PE38KDEL is constructed from a disulfide-stabilized $\mathrm{scFv}$ of the D2C7 antibody fused to the $38 \mathrm{kDa}$ fragment of PE with a carboxy-terminal KDEL sequence to enhance intracellular retrograde trafficking (Figure 3E). Stabilization of the scFv through engineering of a disulfide bridge is thought to improve both $\mathrm{scFv}$ binding affinity and stability. D2C7(scdsFv)-PE38KDEL was highly cytotoxic to glioblastoma cell lines expressing EGFRvIII, as well as non-glioblastoma cell lines with EGFR amplification. Treatment of mice implanted with intracranial EGFRvIII-expressing tumors with D2C7(scdsFv)-PE38KDEL enhanced survival by more than $150 \%$ [134]. Additional studies demonstrated enhanced binding to cancers with EGFR amplification compared to commercial anti-EGFR antibodies and minimal binding to non-tumor tissues in a murine distribution bioassay [85]. These studies have resulted in D2C7(scdsFv)-PE38KDEL receiving Investigational New Drug status and moving to clinical testing [135] in a Phase I/II study to determine maximum-tolerated dose and initial effectiveness in patients with malignant glioma [77].

The 806 monoclonal antibody (m806) has similar properties to D2C7, originally raised in mice against an antigen composed of the unique peptide generated by the EGFRvIII deletion [136]. The m806 antibody binds strongly to cells expressing EGFRvIII, but it also has a novel tumor-specific binding tropism. The 806 antibody only binds cells with overexpression or amplification of EGFR, without binding to cells expressing wild-type EGFR [137]. This unique property is the result of m806 binding a conformational epitope that is masked in inactive or dimerized EGFR and only becomes exposed in the "untethered" form of the receptor $[138,139]$. This transient activated form preferentially occurs in oncogenic cells with enhanced EGFR activation, so m806 binds cells with normal EGFR signaling at very low levels [140]. This unique property suggests it is an ideal candidate for targeting oncogenic cells without off-target effects on healthy tissues. With that in mind, several 806-based immunotoxins have been examined in preclinical studies.

DT390-BiscFv806 contains a bivalent single chain 806 FV fused to the ADP-ribosyltransferase and translocation domains of DT. This immunotoxin inhibited the viability of U87MG glioblastoma 
cells ectopically overexpressing EGFRvIII, as well as a panel of head and neck cancers with EGFR overexpression [71]. 806-PE38 was engineered in a similar fashion, but only contains a single $806 \mathrm{Fv}$ valency and utilizes the PE38 derivative as the cytotoxin component. Preclinical studies demonstrated 806-PE38 inhibition of the viability of triple-negative breast cancers, which commonly show amplification or overexpression of EGFR, at concentrations below $150 \mathrm{pM}$ [70]. 806-PE38 was similarly potent in vivo, enhancing the survival of mice implanted with TNBC xenografts by two-fold. 806-PE38 also was strongly cytotoxic toward epidermoid, breast, and lung cancers with EGFR amplification. 806-PE38 displayed 1000-fold higher inhibition of cell viability over the parental m806 antibody or an anti-EGFR antibody, demonstrating the increase in anti-cancer potency offered by immunotoxin cytotoxic activity over signaling inhibition alone (Figure 4). 806-PE38 was non-toxic to the non-malignant WI-38 epithelial cell line, confirming that the 806 antibody does not target non-malignant cells with normal EGFR expression.

A.

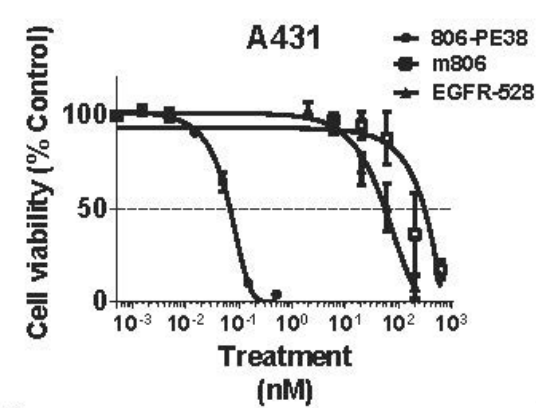

C.

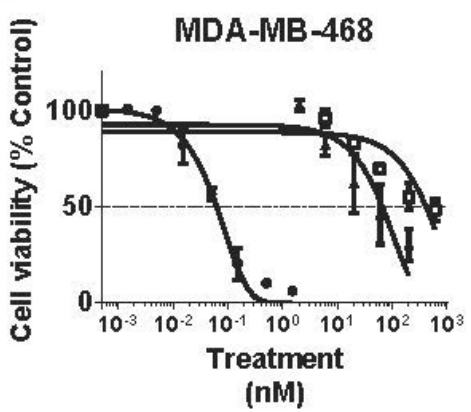

E.

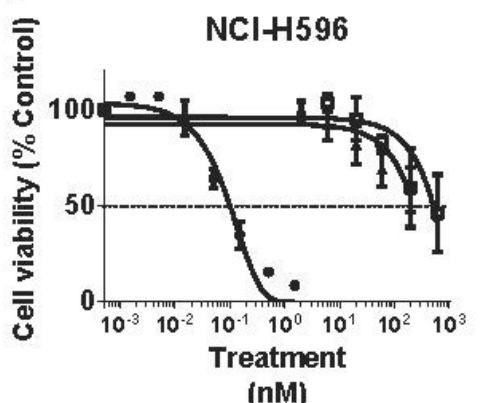

B.

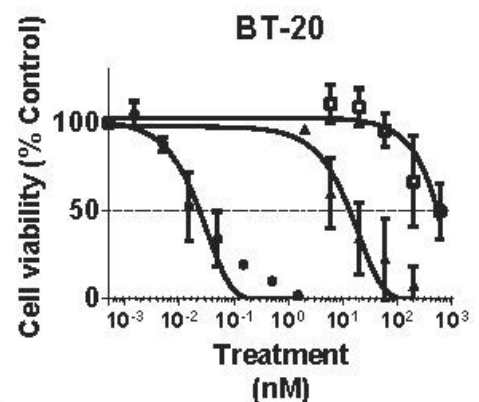

D.

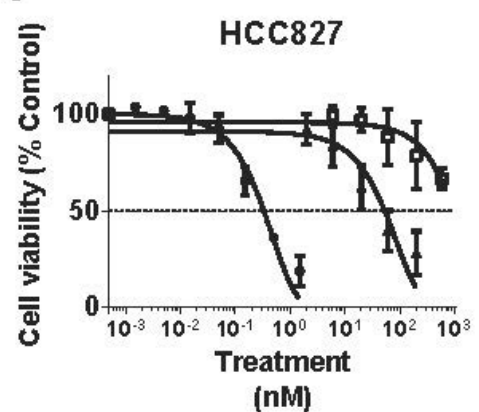

F.

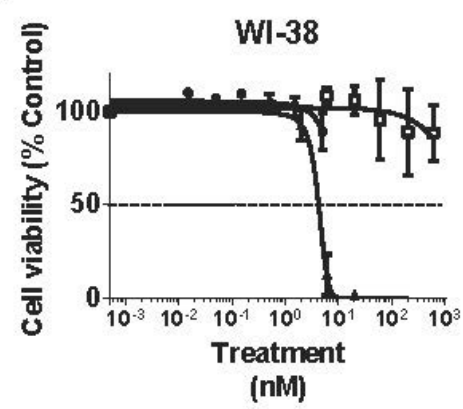

Figure 4. The 806-PE38 immunotoxin is 1000-fold more potent to malignant cells with EGFR overexpression than anti-EGFR antibodies. (A) A431 epidermoid carcinoma (B) BT-20 invasive ductal breast carcinoma (C) MDA-MB-468 triple-negative breast adenocarcinoma (D) HCC827 lung adenocarcinoma (E) NCI-H596 lung adenosquamous carcinoma or (F) WI-38 non-malignant epithelial cells were incubated with the indicated concentrations of 806-PE38 $(\bullet)$, the parental m806 antibody $(\square)$, or the anti-EGFR(528) antibody $(\mathbf{\Delta})$ for $72 \mathrm{~h}$. Cell viability was then measured with the Cell-Titer Glo assay. Data was normalized to a no-toxin control. Each assay was performed in triplicate at least twice. 
A final example of anti-EGFR immunotoxin with the ability to bind both wild type EGFR and EGFRvIII is scFv(14E1)-ETA, consisting of the scFv of the 14E1 monoclonal antibody. 14E1 was isolated from mice immunized with A431 epidermoid carcinoma cells as an EGFR-binding antibody with nine-fold higher affinity for the extracellular domain of EGFR than cetuximab [72]. scFv(14E1)-ETA displayed similar potency as TGF $\alpha$-PE38 against multiple cancer cell lines with EGFR overexpression. Unlike TGF $\alpha$-PE38, however, scFv(14E1)-ETA was not toxic to cells without EGFR overexpression, suggesting it may not target healthy cells with normal EGFR levels. scFv(14E1)-ETA also binds EGFRvIII, displaying 100-fold more potency towards cells with EGFRvIII expression than cells with wild type EGFR [141]. In confirmation of this dual-targeting, $\mathrm{scFv}(14 \mathrm{E} 1)$-ETA proved to be effective at killing glioblastoma cells displaying resistance to both cetuximab and EGFR TKI [142]. Intriguingly, the commonly used chemotherapeutic cisplatin appears to upregulate EGFR in cisplatin-resistant glioblastoma [142]. Co-administration of cisplatin and scFv(14E1)-ETA was significantly more effective at killing the chemotherapy-resistant cells than either treatment alone. In preclinical studies of breast cancer patients, $\mathrm{scFv}$ (14E1)-ETA eliminated breast cancer cells from hematopoietic progenitor cell grafts ex vivo and was cytotoxic to 5/5 patient breast cancer tissue explants [143]. scFv(14E1)-ETA also demonstrated anti-metastatic capabilities, eliminating pulmonary metastases in an immunocompetent mouse model of metastatic renal cancer; however, all mice developed anti-PE antibodies resulting in neutralization of further toxin activity [144]. The ability to use a single therapeutic for cancers expressing either wild type EGFR or EGFRvIII broadly expands the range of cancers for which these molecules could become therapeutic options someday.

\subsection{Photochemical Delivery of Anti-EGFR Immunotoxins}

One potential issue with the use of EGFR-targeted immunotoxins is their necessity for delivery to the cytosol to exert their cytotoxic functions. During normal EGFR trafficking, once activated, the receptor is internalized and either recycled to the cell surface or sent to the lysosome for degradation. However, if the therapeutic does not efficiently escape the endosome and is recycled out to the cell surface or degraded in the lysosome, treatment efficacy would be severely compromised. To circumvent errant immunotoxin delivery, the development of a photochemical internalization (PCI) system to prematurely lyse IT-containing vesicles to deliver the therapeutic directly to the cytosol has been explored for several EGFR-targeted immunotoxins. In PCI, accumulation of a photosensitizer molecule in endosomes and lysosomes was followed by excitation of these molecules through targeted application of light to the tumor results in vesicle rupture, delivering the contents directly to the cytosol [145].

Proof-of-concept experiments demonstrated that toxicity of an EGF-saporin conjugate is enhanced more than 1000-fold when combined with PCI in various malignant cell lines with EGFR expression, while non-toxic to cells without EGFR [146]. Cetuximab possesses a two-log higher affinity for EGFR than EGF, so a similar construct made through the chemical conjugation of the full-length cetuximab antibody to saporin was also examined. Cetuximab-saporin was toxic to colon, prostate, and epithelial cancer cells, and combination with PCI resulted in significantly increased toxicity in all EGFR-expressing cell lines tested [147]. While the use of PCI with EGFR-targeted immunotoxins is relatively early in development, PCI has been used in vivo to enhance other immunotoxin activity with complete remissions observed in a mouse model of melanoma [148]. Similar in application to saponins, it is expected that the addition of PCI to immunotoxin therapy would allow for more effective treatment with fewer off-target effects. The increased bioavailability of active molecules escaping degradation may allow for decreased concentrations of potent therapeutics. When coupled with increased treatment specificity through light application to the tumor site alone, a decrease in off-target effects on non-cancerous tissues can be expected [149]. Future development of PCI in combination with EGFR-targeted immunotoxins may provide significant clinical benefits for patients with light-accessible tumors. 


\section{Conclusions}

Overexpression or amplification of the EGFR generally results in cancers with increased aggressiveness, higher rates of metastases, and worse patient prognosis. With the wide variety of cancers displaying overexpression of wild type EGFR or its mutants, it is of little surprise that so much work has gone into development of a specific and potent anti-EGFR therapeutic. While some success has been achieved in developing potent and lasting inhibition of these cancers, many current treatments prove too limited in duration. The combination of a potent enzymatic cytotoxin with an interchangable cellular targeting domain, unique properties of immunotoxins, explains why these molecules are perfectly suited for future anti-cancer development. Targeting of EGFR or EGFRvIII with various antibodies as a delivery vector for apoptosis-inducing cytotoxins has proven extremely successful in preclinical studies; however, clinical work to date has proven mostly unsuccessful. Increases in antibody and protein engineering techniques allowing for higher affinity binding domains and the removal of immune-stimulating epitopes may yet lead to powerful and safe therapeutics for the treatment of these cancers.

Acknowledgments: This work and open access publication costs were supported by the Intramural Research Program of the National Institutes of Health, National Cancer Institute, Center for Cancer Research.

Conflicts of Interest: The authors declare no conflict of interest.

\section{Abbreviations}

The following abbreviations are used in this manuscript:

EGFR epidermal growth factor receptor

IT immunotoxin

scFv single-chain variable fragment

PE Pseudomonas exotoxin

DT diphtheria toxin

EGF epidermal growth factor

TGF $\alpha \quad$ transforming growth factor alpha

HB-EGF heparin binding-EGF

TKI tyrosine kinase inhibitor

TNBC triple-negative breast cancer

NSCLC non-small cell lung cancer

EF2 elongation factor 2

RIP ribosome-inactivating proteins

$\mathrm{MAb}$ monoclonal antibody

NK cell natural killer cell

CED convection enhanced delivery

PCI photochemical internalization

\section{References}

1. Chong, C.R.; Janne, P.A. The quest to overcome resistance to EGFR-targeted therapies in cancer. Nat. Med. 2013, 19, 1389-1400. [CrossRef] [PubMed]

2. Hynes, N.E.; Lane, H.A. ERBB receptors and cancer: The complexity of targeted inhibitors. Nat. Rev. Cancer 2005, 5, 341-354. [CrossRef] [PubMed]

3. Scaltriti, M.; Baselga, J. The Epidermal Growth Factor Receptor Pathway: A Model for Targeted Therapy. Clin. Cancer Res. 2006, 12, 5268-5272. [CrossRef] [PubMed] 
4. Kobayashi, S.; Boggon, T.J.; Dayaram, T.; Jänne, P.A.; Kocher, O.; Meyerson, M.; Johnson, B.E.; Eck, M.J.; Tenen, D.G.; Halmos, B. EGFR Mutation and Resistance of Non-Small-Cell Lung Cancer to Gefitinib. N. Engl. J. Med. 2005, 352, 786-792. [CrossRef] [PubMed]

5. Lynch, T.J.; Bell, D.W.; Sordella, R.; Gurubhagavatula, S.; Okimoto, R.A.; Brannigan, B.W.; Harris, P.L.; Haserlat, S.M.; Supko, J.G.; Haluska, F.G.; et al. Activating Mutations in the Epidermal Growth Factor Receptor Underlying Responsiveness of Non-Small-Cell Lung Cancer to Gefitinib. N. Engl. J. Med. 2004, 350, 2129-2139. [CrossRef] [PubMed]

6. Gan, H.K.; Cvrljevic, A.N.; Johns, T.G. The epidermal growth factor receptor variant III (EGFRvIII): Where wild things are altered. FEBS J. 2013, 280, 5350-5370. [CrossRef] [PubMed]

7. Nishikawa, R.; Ji, X.D.; Harmon, R.C.; Lazar, C.S.; Gill, G.N.; Cavenee, W.K.; Huang, H.J. A mutant epidermal growth factor receptor common in human glioma confers enhanced tumorigenicity. Proc. Natl. Acad. Sci. USA 1994, 91, 7727-7731. [CrossRef] [PubMed]

8. Tanaka, K.; Babic, I.; Nathanson, D.; Akhavan, D.; Guo, D.; Gini, B.; Dang, J.; Zhu, S.; Yang, H.; De Jesus, J.; et al . Oncogenic EGFR Signaling Activates an mTORC2-NF-kB Pathway That Promotes Chemotherapy Resistance. Cancer Discov. 2011, 1, 524-538. [CrossRef] [PubMed]

9. Nagane, M.; Levitzki, A.; Gazit, A.; Cavenee, W.K.; Huang, H.-J.S. Drug resistance of human glioblastoma cells conferred by a tumor-specific mutant epidermal growth factor receptor through modulation of Bcl-XL and caspase-3-like proteases. Proc. Natl. Acad. Sci. USA 1998, 95, 5724-5729. [CrossRef] [PubMed]

10. Park, H.S.; Jang, M.H.; Kim, E.J.; Kim, H.J.; Lee, H.J.; Kim, Y.J.; Kim, J.H.; Kang, E.; Kim, S.-W.; Kim, I.A.; et al. High EGFR gene copy number predicts poor outcome in triple-negative breast cancer. Mod. Pathol. 2014, 27, 1212-1222. [CrossRef] [PubMed]

11. Lemoine, N.R.; Hughes, C.M.; Barton, C.M.; Poulsom, R.; Jeffery, R.E.; Klöppel, G.; Hall, P.A.; Gullick, W.J. The Epidermal Growth Factor Receptor in Human Pancreatic Cancer. J. Pathol. 1992, 166, 7-12. [CrossRef] [PubMed]

12. Korc, M.; Chandrasekar, B.; Yamanaka, Y.; Friess, H.; Buchier, M.; Beger, H.G. Overexpression of the epidermal growth factor receptor in human pancreatic cancer is associated with concomitant increases in the levels of epidermal growth factor and transforming growth factor alpha. J. Clin. Investig. 1992, 90, 1352-1360. [CrossRef] [PubMed]

13. Grandis, J.R.; Melhem, M.F.; Barnes, E.L.; Tweardy, D.J. Quantitative immunohistochemical analysis of transforming growth factor- $\alpha$ and epidermal growth factor receptor in patients with squamous cell carcinoma of the head and neck. Cancer 1996, 78, 1284-1292. [CrossRef]

14. Hirsch, F.R.; Scagliotti, G.V.; Langer, C.J.; Varella-Garcia, M.; Franklin, W.A. Epidermal growth factor family of receptors in preneoplasia and lung cancer: Perspectives for targeted therapies. Lung Cancer 2003, 41 (Suppl. 1), 29-42. [CrossRef]

15. Rao, J.Y.; Hemstreet, G.P.; Hurst, R.E.; Bonner, R.B.; Jones, P.L.; Min, K.W.; Fradet, Y. Alterations in phenotypic biochemical markers in bladder epithelium during tumorigenesis. Proc. Natl. Acad. Sci. USA 1993, 90, 8287-8291. [CrossRef] [PubMed]

16. Neal, D.; Bennett, M.; Hall, R.; Marsh, C.; Abel, P.; Sainsbury, J.R.C.; Harris, A. Epidermal-growth-factor receptors in human bladder cancer: Comparison of invasive and superficial tumours. Lancet 1985, 325, 366-368. [CrossRef]

17. Wikstrand, C.J.; Hale, L.P.; Batra, S.K.; Hill, M.L.; Humphrey, P.A.; Kurpad, S.N.; McLendon, R.E.; Moscatello, D.; Pegram, C.N.; Reist, C.J.; et al. Monoclonal Antibodies against EGFRvIII Are Tumor Specific and React with Breast and Lung Carcinomas and Malignant Gliomas. Cancer Res. 1995, 55, 3140-3148. [PubMed]

18. Wikstrand, C.J.; McLendon, R.E.; Friedman, A.H.; Bigner, D.D. Cell Surface Localization and Density of the Tumor-associated Variant of the Epidermal Growth Factor Receptor, EGFRvIII. Cancer Res. 1997, 57, 4130-4140. [PubMed]

19. Arteaga, C.L.; Engelman, J.A. ERBB Receptors: From Oncogene Discovery to Basic Science to Mechanism-Based Cancer Therapeutics. Cancer Cell 2014, 25, 282-303.

20. Salomon, D.S.; Brandt, R.; Ciardiello, F.; Normanno, N. Epidermal growth factor-related peptides and their receptors in human malignancies. Crit. Rev. Oncol. Hematol. 1995, 19, 183-232. [CrossRef]

21. Nicholson, R.I.; Gee, J.M.W.; Harper, M.E. EGFR and cancer prognosis. Eur. J. Cancer 2001, 37 (Suppl. 4), 9-15. [CrossRef] 
22. Martinelli, E.; De Palma, R.; Orditura, M.; De Vita, F.; Ciardiello, F. Anti-epidermal growth factor receptor monoclonal antibodies in cancer therapy. Clin. Exp. Immunol. 2009, 158, 1-9. [CrossRef] [PubMed]

23. Eriksen, J.G.; Maare, C.; Johansen, J.; Primdahl, H.; Evensen, J.F.; Kristensen, C.A.; Andersen, L.J.; Overgaard, J. Evaluation of the EGFR-Inhibitor Zalutumumab Given with Primary Curative (Chemo)radiation Therapy to Patients with Squamous Cell Carcinoma of the Head and Neck: Results of the DAHANCA 19 Randomized Phase 3 Trial. Int. J. Radiat. Oncol. Biol. Phys. 2014, 88, 465. [CrossRef]

24. Westphal, M.; Heese, O.; Steinbach, J.P.; Schnell, O.; Schackert, G.; Mehdorn, M.; Schulz, D.; Simon, M.; Schlegel, U.; Senft, C.; et al. A randomised, open label phase III trial with nimotuzumab, an anti-epidermal growth factor receptor monoclonal antibody in the treatment of newly diagnosed adult glioblastoma. Eur. J. Cancer 2015, 51, 522-532. [CrossRef] [PubMed]

25. Schiller, J.H.; von Pawel, J.; Schütt, P.; Ansari, R.H.; Thomas, M.; Saleh, M.; McCroskey, R.D.; Pfeifer, W.; Marsland, T.A.; Kloecker, G.H.; et al. Pemetrexed with or without Matuzumab as Second-Line Treatment for Patients with Stage IIIB/IV Non-small Cell Lung Cancer. J. Thoracic Oncol. 2010, 5, 1977-1985. [CrossRef] [PubMed]

26. Seiden, M.V.; Burris, H.A.; Matulonis, U.; Hall, J.B.; Armstrong, D.K.; Speyer, J.; Weber, J.D.A.; Muggia, F. A phase II trial of EMD72000 (matuzumab), a humanized anti-EGFR monoclonal antibody, in patients with platinum-resistant ovarian and primary peritoneal malignancies. Gynecol. Oncol. 2007, 104, 727-731. [CrossRef] [PubMed]

27. Beidler, C.B.; Petrovan, R.J.; Conner, E.M.; Boyles, J.S.; Yang, D.D.; Harlan, S.M.; Chu, S.; Ellis, B.; Datta-Mannan, A.; Johnson, R.L.; et al. Generation and Activity of a Humanized Monoclonal Antibody That Selectively Neutralizes the Epidermal Growth Factor Receptor Ligands Transforming Growth Factor- $\alpha$ and Epiregulin. J. Pharmacol. Exp. Ther. 2014, 349, 330-343. [CrossRef] [PubMed]

28. Miyamoto, S.; Iwamoto, R.; Furuya, A.; Takahashi, K.; Sasaki, Y.; Ando, H.; Yotsumoto, F.; Yoneda, T.; Hamaoka, M.; Yagi, H.; et al. A Novel Anti-Human HB-EGF Monoclonal Antibody with Multiple Antitumor Mechanisms against Ovarian Cancer Cells. Clin. Cancer Res. 2011, 17, 6733-6741. [CrossRef] [PubMed]

29. Lindzen, M.; Lavi, S.; Leitner, O.; Yarden, Y. Tailored cancer immunotherapy using combinations of chemotherapy and a mixture of antibodies against EGF-receptor ligands. Proc. Natl. Acad. Sci. USA 2010, 107, 12559-12563. [CrossRef] [PubMed]

30. Mok, T.S.; Wu, Y.-L.; Thongprasert, S.; Yang, C.-H.; Chu, D.-T.; Saijo, N.; Sunpaweravong, P.; Han, B.; Margono, B.; Ichinose, Y.; et al. Gefitinib or Carboplatin-Paclitaxel in Pulmonary Adenocarcinoma. N. Engl. J. Med. 2009, 361, 947-957. [CrossRef] [PubMed]

31. Shepherd, F.A.; Rodrigues Pereira, J.; Ciuleanu, T.; Tan, E.H.; Hirsh, V.; Thongprasert, S.; Campos, D.; Maoleekoonpiroj, S.; Smylie, M.; Martins, R.; et al. Erlotinib in Previously Treated Non-Small-Cell Lung Cancer. N. Engl. J. Med. 2005, 353, 123-132. [CrossRef] [PubMed]

32. Moore, M.J.; Goldstein, D.; Hamm, J.; Figer, A.; Hecht, J.R.; Gallinger, S.; Au, H.J.; Murawa, P.; Walde, D.; Wolff, R.A.; et al. Erlotinib Plus Gemcitabine Compared With Gemcitabine Alone in Patients With Advanced Pancreatic Cancer: A Phase III Trial of the National Cancer Institute of Canada Clinical Trials Group. Chin. Ger. J. Clin. Oncol. 2007, 25, 1960-1966. [CrossRef] [PubMed]

33. Geyer, C.E.; Forster, J.; Lindquist, D.; Chan, S.; Romieu, C.G.; Pienkowski, T.; Jagiello-Gruszfeld, A.; Crown, J.; Chan, A.; Kaufman, B.; et al. Lapatinib plus Capecitabine for HER2-Positive Advanced Breast Cancer. N. Engl. J. Med. 2006, 355, 2733-2743. [CrossRef] [PubMed]

34. Su, K.-Y.; Chen, H.-Y.; Li, K.-C.; Kuo, M.-L.; Yang, J.C.-H.; Chan, W.-K.; Ho, B.-C.; Chang, G.-C.; Shih, J.-Y.; Yu, S.-L.; et al. Pretreatment Epidermal Growth Factor Receptor (EGFR) T790M Mutation Predicts Shorter EGFR Tyrosine Kinase Inhibitor Response Duration in Patients With Non-Small-Cell Lung Cancer. Chin. Ger. J. Clin. Oncol. 2012, 30, 433-440. [CrossRef] [PubMed]

35. Cross, D.A.E.; Ashton, S.E.; Ghiorghiu, S.; Eberlein, C.; Nebhan, C.A.; Spitzler, P.J.; Orme, J.P.; Finlay, M.R.V.; Ward, R.A.; Mellor, M.J.; et al. AZD9291, an Irreversible EGFR TKI, Overcomes T790M-Mediated Resistance to EGFR Inhibitors in Lung Cancer. Cancer Discov. 2014, 4, 1046-1061. [CrossRef] [PubMed]

36. Yang, J.C.-H.; Wu, Y.-L.; Schuler, M.; Sebastian, M.; Popat, S.; Yamamoto, N.; Zhou, C.; Hu, C.-P.; O’Byrne, K.; Feng, J.; et al. Afatinib versus cisplatin-based chemotherapy for EGFR mutation-positive lung adenocarcinoma (LUX-Lung 3 and LUX-Lung 6): Analysis of overall survival data from two randomised, phase 3 trials. Lancet Oncol. 2015, 16, 141-151. [CrossRef] 
37. Walter, A.O.; Sjin, R.T.T.; Haringsma, H.J.; Ohashi, K.; Sun, J.; Lee, K.; Dubrovskiy, A.; Labenski, M.; Zhu, Z.; Wang, Z.; et al. Discovery of a Mutant-Selective Covalent Inhibitor of EGFR that Overcomes T790M-Mediated Resistance in NSCLC. Cancer Discov. 2013, 3, 1404-1415. [CrossRef] [PubMed]

38. Park, K.; Lee, J.-S.; Lee, K.H.; Kim, J.-H.; Min, Y.J.; Cho, J.Y.; Han, J.-Y.; Kim, B.-S.; Kim, J.-S.; Lee, D.H.; et al. Updated safety and efficacy results from phase I/II study of HM61713 in patients (pts) with EGFR mutation positive non-small cell lung cancer (NSCLC) who failed previous EGFR-tyrosine kinase inhibitor (TKI). In Proceedings of ASCO Annual Meeting, Chicago, IL, USA, 29 May-2 June 2015; p. 8084.

39. Nathanson, D.A.; Gini, B.; Mottahedeh, J.; Visnyei, K.; Koga, T.; Gomez, G.; Eskin, A.; Hwang, K.; Wang, J.; Masui, K.; et al. Targeted Therapy Resistance Mediated by Dynamic Regulation of Extrachromosomal Mutant EGFR DNA. Science 2014, 343, 72-76. [CrossRef] [PubMed]

40. Widakowich, C.; de Castro, G.; de Azambuja, E.; Dinh, P.; Awada, A. Review: Side Effects of Approved Molecular Targeted Therapies in Solid Cancers. Oncologist 2007, 12, 1443-1455. [CrossRef] [PubMed]

41. Blythman, H.E.; Casellas, P.; Gros, O.; Gros, P.; Jansen, F.K.; Paolucci, F.; Pau, B.; Vidal, H. Immunotoxins: Hybrid molecules of monoclonal antibodies and a toxin subunit specifically kill tumour cells. Nature 1981, 290, 145-146. [CrossRef] [PubMed]

42. Antignani, A.; Fitzgerald, D. Immunotoxins: The role of the toxin. Toxins 2013, 5, 1486-1502. [CrossRef] [PubMed]

43. Collier, R.J. Effect of diphtheria toxin on protein synthesis: Inactivation of one of the transfer factors. J. Mol. Biol. 1967, 25, 83-98. [CrossRef]

44. Iglewski, B.H.; Liu, P.V.; Kabat, D. Mechanism of action of Pseudomonas aeruginosa exotoxin A: Adenosine diphosphate ribosylation of mammalian elongation factor 2 in vitro and in vivo. Infect. Immun. 1977, 15, 138-144. [PubMed]

45. Morimoto, H.; Bonavida, B. Diphtheria toxin- and Pseudomonas A toxin-mediated apoptosis. ADP ribosylation of elongation factor-2 is required for DNA fragmentation and cell lysis and synergy with tumor necrosis factor-alpha. J. Immunol. 1992, 149, 2089-2094. [PubMed]

46. Sandvig, K.; Olsnes, S. Diphtheria toxin entry into cells is facilitated by low pH. J. Cell Biol. 1980, 87, 828-832. [CrossRef] [PubMed]

47. Weldon, J.E.; Pastan, I. A guide to taming a toxin-recombinant immunotoxins constructed from Pseudomonas exotoxin A for the treatment of cancer. FEBS J. 2011, 278, 4683-4700. [CrossRef] [PubMed]

48. Yamaizumi, M.; Mekada, E.; Uchida, T.; Okada, Y. One molecule of diphtheria toxin fragment A introduced into a cell can kill the cell. Cell 1978, 15, 245-250. [CrossRef]

49. Yokota, T.; Milenic, D.E.; Whitlow, M.; Schlom, J. Rapid Tumor Penetration of a Single-Chain Fv and Comparison with Other Immunoglobulin Forms. Cancer Res. 1992, 52, 3402-3408. [PubMed]

50. Sandvig, K.; van Deurs, B. Delivery into cells: Lessons learned from plant and bacterial toxins. Gene Ther. 2005, 12, 865-872. [CrossRef] [PubMed]

51. Banker, D.E.; Pastan, I.; Gottesman, M.M.; Herschman, H.R. An epidermal growth factor-ricin a chain (EGF-RTA)-resistant mutant and an epidermal growth factor-Pseudomonas endotoxin (EGF-PE)-resistant mutant have distinct phenotypes. J. Cell. Physiol. 1989, 139, 51-57. [CrossRef] [PubMed]

52. Lindstrom, A.L.; Erlandsen, S.L.; Kersey, J.H.; Pennell, C.A. An in vitro model for toxin-mediated vascular leak syndrome: ricin toxin A chain increases the permeability of human endothelial cell monolayers. Blood 1997, 90, 2323-2334. [PubMed]

53. Hassan, R.; Bullock, S.; Premkumar, A.; Kreitman, R.J.; Kindler, H.; Willingham, M.C.; Pastan, I. Phase I study of SS1P, a recombinant anti-mesothelin immunotoxin given as a bolus I.V. infusion to patients with mesothelin-expressing mesothelioma, ovarian, and pancreatic cancers. Clin. Cancer Res. 2007, 13, 5144-5149. [CrossRef] [PubMed]

54. Onda, M.; Ghoreschi, K.; Steward-Tharp, S.; Thomas, C.; O'Shea, J.J.; Pastan, I.H.; FitzGerald, D.J. Tofacitinib suppresses antibody responses to protein therapeutics in murine hosts. J. Immunol. 2014, 193, 48-55. [CrossRef] [PubMed]

55. Hassan, R.; Miller, A.C.; Sharon, E.; Thomas, A.; Reynolds, J.C.; Ling, A.; Kreitman, R.J.; Miettinen, M.M.; Steinberg, S.M.; Fowler, D.H.; et al. Major cancer regressions in mesothelioma after treatment with an anti-mesothelin immunotoxin and immune suppression. Sci. Transl. Med. 2013, 5, 208ra147. [CrossRef] [PubMed] 
56. Onda, M.; Beers, R.; Xiang, L.; Nagata, S.; Wang, Q.-C.; Pastan, I. An immunotoxin with greatly reduced immunogenicity by identification and removal of B cell epitopes. Proc. Natl. Acad. Sci. USA 2008, 105, 11311-11316. [CrossRef] [PubMed]

57. Mazor, R.; Crown, D.; Addissie, S.; Jang, Y.; Kaplan, G.; Pastan, I. Elimination of murine and human T-cell epitopes in recombinant immunotoxin eliminates neutralizing and anti-drug antibodies in vivo. Cell Mol. Immunol. 2015. [CrossRef] [PubMed]

58. Olsen, E.; Duvic, M.; Frankel, A.; Kim, Y.; Martin, A.; Vonderheid, E.; Jegasothy, B.; Wood, G.; Gordon, M.; Heald, P.; et al. Pivotal phase III trial of two dose levels of denileukin diftitox for the treatment of cutaneous T-cell lymphoma. J. Clin. Oncol. 2001, 19, 376-388. [PubMed]

59. Hassan, R.; Sharon, E.; Thomas, A.; Zhang, J.; Ling, A.; Miettinen, M.; Kreitman, R.J.; Steinberg, S.M.; Hollevoet, K.; Pastan, I. Phase 1 study of the antimesothelin immunotoxin SS1P in combination with pemetrexed and cisplatin for front-line therapy of pleural mesothelioma and correlation of tumor response with serum mesothelin, megakaryocyte potentiating factor, and cancer antigen 125. Cancer 2014, 120, 3311-3319. [PubMed]

60. Kreitman, R.J.; Tallman, M.S.; Robak, T.; Coutre, S.; Wilson, W.H.; Stetler-Stevenson, M.; Fitzgerald, D.J.; Lechleider, R.; Pastan, I. Phase I trial of anti-CD22 recombinant immunotoxin moxetumomab pasudotox (CAT-8015 or HA22) in patients with hairy cell leukemia. J. Clin. Oncol. 2012, 30, 1822-1828. [CrossRef] [PubMed]

61. Chaudhary, V.K.; FitzGerald, D.J.; Adhya, S.; Pastan, I. Activity of a recombinant fusion protein between transforming growth factor type alpha and Pseudomonas toxin. Proc. Natl. Acad. Sci. USA 1987, 84, 4538-4542. [CrossRef] [PubMed]

62. Thakur, M.; Mergel, K.; Weng, A.; von Mallinckrodt, B.; Gilabert-Oriol, R.; Dürkop, H.; Melzig, M.F.; Fuchs, H. Targeted tumor therapy by epidermal growth factor appended toxin and purified saponin: An evaluation of toxicity and therapeutic potential in syngeneic tumor bearing mice. Mol. Oncol. 2013, 7, 475-483. [CrossRef] [PubMed]

63. Wels, W.; Beerli, R.; Hellmann, P.; Schmidt, M.; Marte, B.M.; Kornilova, E.S.; Hekele, A.; Mendelsohn, J.; Groner, B.; Hynes, N.E. EGF receptor and p185erbB-2-specific single-chain antibody toxins differ in their cell-killing activity on tumor cells expressing both receptor proteins. Int. J. Cancer 1995, 60, 137-144. [CrossRef] [PubMed]

64. Bruell, D.; Stöcker, M.; Huhn, M.; Redding, N.; Küpper, M.; Schumacher, P.; Paetz, A.; Bruns, C.J.; Haisma, H.J.; Fischer, R.; et al. The recombinant anti-EGF receptor immunotoxin 425(scFv)-ETA' suppresses growth of a highly metastatic pancreatic carcinoma cell line. Int. J. Oncol. 2003, 23, 1179-1186. [PubMed]

65. Niesen, J.; Stein, C.; Brehm, H.; Hehmann-Titt, G.; Fendel, R.; Melmer, G.; Fischer, R.; Barth, S. Novel EGFR-specific immunotoxins based on panitumumab and cetuximab show in vitro and ex vivo activity against different tumor entities. J. Cancer Res. Clin. Oncol. 2015, 141, 2079-2095. [CrossRef] [PubMed]

66. Gilabert-Oriol, R.; Thakur, M.; von Mallinckrodt, B.; Hug, T.; Wiesner, B.; Eichhorst, J.; Melzig, M.F.; Fuchs, H.; Weng, A. Modified Trastuzumab and Cetuximab Mediate Efficient Toxin Delivery While Retaining Antibody-Dependent Cell-Mediated Cytotoxicity in Target Cells. Mol. Pharm. 2013, 10, 4347-4357. [CrossRef] [PubMed]

67. Gilabert-Oriol, R.; Weng, A.; Trautner, A.; Weise, C.; Schmid, D.; Bhargava, C.; Niesler, N.; Wookey, P.J.; Fuchs, H.; Thakur, M. Combinatorial approach to increase efficacy of Cetuximab, Panitumumab and Trastuzumab by dianthin conjugation and co-application of SO1861. Biochem. Pharmacol. 2015, 97, 247-255. [CrossRef] [PubMed]

68. Lorimer, I.A.; Wikstrand, C.J.; Batra, S.K.; Bigner, D.D.; Pastan, I. Immunotoxins that target an oncogenic mutant epidermal growth factor receptor expressed in human tumors. Clin. Cancer Res. 1995, 1, 859-864. [PubMed]

69. Lorimer, I.A.; Keppler-Hafkemeyer, A.; Beers, R.A.; Pegram, C.N.; Bigner, D.D.; Pastan, I. Recombinant immunotoxins specific for a mutant epidermal growth factor receptor: Targeting with a single chain antibody variable domain isolated by phage display. Proc. Natl. Acad. Sci. USA 1996, 93, 14815-14820. [CrossRef] [PubMed]

70. Simon, N.; Antignani, A.; Sarnovsky, R.; Hewitt, S.M.; FitzGerald, D. Targeting a Cancer-Specific Epitope of the Epidermal Growth Factor Receptor in Triple-Negative Breast Cancer. J. Natl. Cancer Inst. 2016, 108. [CrossRef] [PubMed] 
71. Meng, J.; Liu, Y.; Gao, S.; Lin, S.; Gu, X.; Pomper, M.G.; Wang, P.C.; Shan, L. A bivalent recombinant immunotoxin with high potency against tumors with EGFR and EGFRvIII expression. Cancer Biol. Ther. 2015, 16, 1764-1774. [CrossRef] [PubMed]

72. Schmidt, M.; Vakalopoulou, E.; Schneider, D.W.; Wels, W. Construction and functional characterization of scFv(14E1)-ETA-A novel, highly potent antibody-toxin specific for the EGF receptor. Br. J. Cancer 1997, 75, 1575-1584. [CrossRef] [PubMed]

73. Sampson, J.H.; Akabani, G.; Archer, G.E.; Bigner, D.D.; Berger, M.S.; Friedman, A.H.; Friedman, H.S.; Herndon, J.E., 2nd; Kunwar, S.; Marcus, S.; et al. Progress report of a Phase I study of the intracerebral microinfusion of a recombinant chimeric protein composed of transforming growth factor (TGF)-alpha and a mutated form of the Pseudomonas exotoxin termed PE-38 (TP-38) for the treatment of malignant brain tumors. J. Neurooncol. 2003, 65, 27-35.

74. Sampson, J.H.; Akabani, G.; Archer, G.E.; Berger, M.S.; Coleman, R.E.; Friedman, A.H.; Friedman, H.S.; Greer, K.; Herndon, J.E., 2nd; Kunwar, S.; et al. Intracerebral infusion of an EGFR-targeted toxin in recurrent malignant brain tumors. Neuro. Oncol. 2008, 10, 320-329.

75. Theodoulou, M.; Baselga, J.; Scher, H.; Dantis, L.; Trainor, K.; Mendelsohn, J.; Howes, L.; Elledge, R.; Ravdin, P.; Bacha, P.; et al. Phase I dose-escalation study of the safety, tolerability, pharmacokinetics and biologic effects of DAB389EGF in patients with solid malignancies that express EGF receptors (EGFR). Proc. Am. Soc. Clin. Oncol. 1995, 14, 480.

76. Bigner, D. Study of Immunotoxin, MR1-1 (MR1-1). Available online: https://clinicaltrials.gov/ct2/show / NCT01009866 (accessed on 22 March 2016).

77. Bigner, D. D2C7 for Adult Patients With Recurrent Malignant Glioma. Available online: https:/ / clinicaltrials. gov/ct2/show / NCT02303678 (accessed on 22 March 2016).

78. Johannes, L.; Decaudin, D. Protein toxins: Intracellular trafficking for targeted therapy. Gene Ther. 2005, 12, 1360-1368. [CrossRef] [PubMed]

79. Heimbrook, D.C.; Stirdivant, S.M.; Ahern, J.D.; Balishin, N.L.; Patrick, D.R.; Edwards, G.M.; Defeo-Jones, D.; FitzGerald, D.J.; Pastan, I.; Oliff, A. Transforming growth factor alpha-Pseudomonas exotoxin fusion protein prolongs survival of nude mice bearing tumor xenografts. Proc. Natl. Acad. Sci. USA 1990, 87, 4697-4701. [CrossRef] [PubMed]

80. Pai, L.H.; Gallo, M.G.; FitzGerald, D.J.; Pastan, I. Antitumor Activity of a Transforming Growth Factor $\alpha$-Pseudomonas Exotoxin Fusion Protein (TGF- $\alpha$-PE40). Cancer Res. 1991, 51, 2808-2812. [PubMed]

81. Kihara, A.; Pastan, I. Small Chimeric Toxins Containing Only Transforming Growth Factor $\alpha$ and Domain III of Pseudomonas Exotoxin with Good Antitumor Activity in Mice. Cancer Res. 1994, 54, 5154-5159. [PubMed]

82. Theuer, C.P.; FitzGerald, D.J.; Pastan, I. A recombinant form of Pseudomonas exotoxin A containing transforming growth factor alpha near its carboxyl terminus for the treatment of bladder cancer. J. Urol. 1993, 149, 1626-1632. [PubMed]

83. Phillips, P.C.; Levow, C.; Catterall, M.; Colvin, O.M.; Pastan, I.; Brem, H. Transforming growth factor-alpha-Pseudomonas exotoxin fusion protein (TGF-alpha-PE38) treatment of subcutaneous and intracranial human glioma and medulloblastoma xenografts in athymic mice. Cancer Res. 1994, 54, 1008-1015. [PubMed]

84. Shaw, J.P.; Akiyoshi, D.E.; Arrigo, D.A.; Rhoad, A.E.; Sullivan, B.; Thomas, J.; Genbauffe, F.S.; Bacha, P.; Nichols, J.C. Cytotoxic properties of DAB486EGF and DAB389EGF, epidermal growth factor (EGF) receptor-targeted fusion toxins. J. Biol. Chem. 1991, 266, 21118-21124. [PubMed]

85. Zalutsky, M.R.; Boskovitz, A.; Kuan, C.-T.; Pegram, C.N.; Ayriss, J.; Wikstrand, C.J.; Buckley, A.F.; Lipp, E.S.; Herndon, J.E., II; McLendon, R.E.; et al. Radioimmunotargeting of malignant glioma by monoclonal antibody D2C7 reactive against both wild-type and variant III mutant epidermal growth factor receptors. Nucl. Med. Biol. 2012, 39, 23-34. [CrossRef] [PubMed]

86. Mellon, J.K.; Cook, S.; Chambers, P.; Neal, D.E. Transforming growth factor alpha and epidermal growth factor levels in bladder cancer and their relationship to epidermal growth factor receptor. Br. J. Cancer 1996, 73, 654-658. [CrossRef] [PubMed]

87. Sarosdy, M.F.; Hutzler, D.H.; Yee, D.; Von Hoff, D.D. In vitro sensitivity testing of human bladder cancers and cell lines to TP-40, a hybrid protein with selective targeting and cytotoxicity. J. Urol. 1993, 150, 1950-1955. [PubMed] 
88. Kameyama, S.; Kawamata, H.; Pastan, I.; Oyasu, R. Cytotoxic effect of a fusion protein from transforming growth factor alpha and Pseudomonas exotoxin on rat and human bladder carcinoma cells in vitro. J. Cancer Res. Clin. Oncol. 1994, 120, 507-512. [CrossRef] [PubMed]

89. Goldberg, M.R.; Heimbrook, D.C.; Russo, P.; Sarosdy, M.F.; Greenberg, R.E.; Giantonio, B.J.; Linehan, W.M.; Walther, M.; Fisher, H.A.; Messing, E. Phase I clinical study of the recombinant oncotoxin TP40 in superficial bladder cancer. Clin. Cancer Res. 1995, 1, 57-61. [PubMed]

90. Cawley, D.B.; Herschman, H.R.; Gary Gilliland, D.; John Collier, R. Epidermal growth factor-toxin A chain conjugates: EGF-Ricin A is a potent toxin while EGF-diphtheria fragment A is nontoxic. Cell 1980, 22, 563-570. [CrossRef]

91. Yang, X.; Kessler, E.; Su, L.-J.; Thorburn, A.; Frankel, A.E.; Li, Y.; La Rosa, F.G.; Shen, J.; Li, C.-Y.; Varella-Garcia, M.; et al. Diphtheria Toxin-Epidermal Growth Factor Fusion Protein DAB(389)EGF for the Treatment of Bladder Cancer. Clin. Cance. Res. 2013, 19, 148-157. [CrossRef] [PubMed]

92. Liu, T.F.; Cohen, K.A.; Ramage, J.G.; Willingham, M.C.; Thorburn, A.M.; Frankel, A.E. A Diphtheria Toxin-Epidermal Growth Factor Fusion Protein Is Cytotoxic to Human Glioblastoma Multiforme Cells. Cancer Res. 2003, 63, 1834-1837. [PubMed]

93. Liu, T.F.; Hall, P.D.; Cohen, K.A.; Willingham, M.C.; Cai, J.; Thorburn, A.; Frankel, A.E. Interstitial Diphtheria Toxin-Epidermal Growth Factor Fusion Protein Therapy Produces Regressions of Subcutaneous Human Glioblastoma Multiforme Tumors in Athymic Nude Mice. Clin. Cancer Res. 2005, 11, 329-334. [PubMed]

94. Huang, J.; Li, Y.M.; Massague, J.; Sicheneder, A.; Vallera, D.A.; Hall, W.A. Intracerebral infusion of the bispecific targeted toxin DTATEGF in a mouse xenograft model of a human metastatic non-small cell lung cancer. J. Neuro-Oncol. 2012, 109, 229-238. [CrossRef] [PubMed]

95. FitzGerald, D.J.; Padmanabhan, R.; Pastan, I.; Willingham, M.C. Adenovirus-induced release of epidermal growth factor and pseudomonas toxin into the cytosol of $\mathrm{KB}$ cells during receptor-mediated endocytosis. Cell 1983, 32, 607-617. [CrossRef]

96. Chandler, L.A.; Sosnowski, B.A.; McDonald, J.R.; Price, J.E.; Aukerman, S.L.; Baird, A.; Pierce, G.F.; Houston, L.L. Targeting tumor cells via EGF receptors: Selective toxicity of an HBEGF-toxin fusion protein. Int. J. Cancer 1998, 78, 106-111. [CrossRef]

97. Chen, C.; Li, J.; Micko, C.J.; Pierce, G.F.; Cunningham, M.R.; Lumsden, A.B. Cytotoxic Effects of Basic FGF and Heparin Binding EGF Conjugated with Cytotoxin Saporin on Vascular Cell Cultures. J. Surg. Res. 1998, 75, 35-41. [CrossRef] [PubMed]

98. Scott, A.M.; Wolchok, J.D.; Old, L.J. Antibody therapy of cancer. Nat. Rev. Cancer 2012, 12, 278-287. [CrossRef] [PubMed]

99. Van Gog, F.B.; Brakenhoff, R.H.; Stigter-van Walsum, M.; Snow, G.B.; van Dongen, G.A.M.S. Perspectives of combined radioimmunotherapy and anti-EGFR antibody therapy for the treatment of residual head and neck cancer. Int. J. Cancer 1998, 77, 13-18. [CrossRef]

100. Perrotte, P.; Matsumoto, T.; Inoue, K.; Kuniyasu, H.; Eve, B.Y.; Hicklin, D.J.; Radinsky, R.; Dinney, C.P.N. Anti-epidermal Growth Factor Receptor Antibody C225 Inhibits Angiogenesis in Human Transitional Cell Carcinoma Growing Orthotopically in Nude Mice. Clin. Cancer Res. 1999, 5, 257-264. [PubMed]

101. Baselga, J.; Norton, L.; Masui, H.; Pandiella, A.; Coplan, K.; Miller, W.H.; Mendelsohn, J. Antitumor Effects of Doxorubicin in Combination With Anti-epidermal Growth Factor Receptor Monoclonal Antibodies. J. Natl. Cancer Inst. 1993, 85, 1327-1333. [CrossRef]

102. Fan, Z.; Baselga, J.; Masui, H.; Mendelsohn, J. Antitumor Effect of Anti-Epidermal Growth Factor Receptor Monoclonal Antibodies plus cis-Diamminedichloroplatinum on Well Established A431 Cell Xenografts. Cancer Res. 1993, 53, 4637-4642. [PubMed]

103. Sato, J.D.; Kawamoto, T.; Le, A.D.; Mendelsohn, J.; Polikoff, J.; Sato, G.H. Biological effects in vitro of monoclonal antibodies to human epidermal growth factor receptors. Mol. Biol. Med. 1983, 1, 511-529. [PubMed]

104. Sunada, H.; Magun, B.E.; Mendelsohn, J.; MacLeod, C.L. Monoclonal antibody against epidermal growth factor receptor is internalized without stimulating receptor phosphorylation. Proc. Natl. Acad. Sci. USA 1986, 83, 3825-3829. [CrossRef] [PubMed]

105. Azemar, M.; Schmidt, M.; Arlt, F.; Kennel, P.; Brandt, B.; Papadimitriou, A.; Groner, B.; Wels, W. Recombinant antibody toxins specific for ErbB2 and EGF receptor inhibit the in vitro growth of human head and neck cancer cells and cause rapid tumor regression in vivo. Int. J. Cancer 2000, 86, 269-275. [CrossRef] 
106. Murthy, U.; Basu, A.; Rodeck, U.; Herlyn, M.; Ross, A.H.; Das, M. Binding of an antagonistic monoclonal antibody to an intact and fragmented EGF-receptor polypeptide. Arch. Biochem. Biophys. 1987, 252, 549-560. [CrossRef]

107. Kamat, V.; Donaldson, J.M.; Kari, C.; Quadros, M.R.D.; Lelkes, P.I.; Chaiken, I.; Cocklin, S.; Williams, J.C.; Papazoglou, E.; Rodeck, U. Enhanced EGFR inhibition and distinct epitope recognition by EGFR antagonistic MABS C225 and 425. Cancer Biol. Ther. 2008, 7, 726-733. [CrossRef] [PubMed]

108. Rodeck, U.; Herlyn, M.; Herlyn, D.; Molthoff, C.; Atkinson, B.; Varello, M.; Steplewski, Z.; Koprowski, H. Tumor Growth Modulation by a Monoclonal Antibody to the Epidermal Growth Factor Receptor: Immunologically Mediated and Effector Cell-independent Effects. Cancer Res. 1987, 47, 3692-3696. [PubMed]

109. Bruell, D.; Bruns, C.J.; Yezhelyev, M.; Huhn, M.; Müller, J.; Ischenko, I.; Fischer, R.; Finnern, R.; Jauch, K.; Barth, S. Recombinant anti-EGFR immunotoxin 425(scFv)-ETA' demonstrates anti-tumor activity against disseminated human pancreatic cancer in nude mice. Int. J. Mol. Med. 2005, 15, 305-313. [CrossRef] [PubMed]

110. Niesen, J.; Brehm, H.; Stein, C.; Berges, N.; Pardo, A.; Fischer, R.; Haaf, A.; Gattenlöhner, S.; Tur, M.K.; Barth, S. In vitro effects and ex vivo binding of an EGFR-specific immunotoxin on rhabdomyosarcoma cells. J. Cancer Res. Clin. Oncol. 2014, 141, 1049-1061. [CrossRef] [PubMed]

111. Galizia, G.; Lieto, E.; De Vita, F.; Orditura, M.; Castellano, P.; Troiani, T.; Imperatore, V.; Ciardiello, F. Cetuximab, a chimeric human mouse anti-epidermal growth factor receptor monoclonal antibody, in the treatment of human colorectal cancer. Oncogene 2007, 26, 3654-3660. [CrossRef] [PubMed]

112. Yang, X.-D.; Jia, X.-C.; Corvalan, J.R.F.; Wang, P.; Davis, C.G.; Jakobovits, A. Eradication of Established Tumors by a Fully Human Monoclonal Antibody to the Epidermal Growth Factor Receptor without Concomitant hemotherapy. Cancer Res. 1999, 59, 1236-1243. [PubMed]

113. Voigt, M.; Braig, F.; Göthel, M.; Schulte, A.; Lamszus, K.; Bokemeyer, C.; Binder, M. Functional Dissection of the Epidermal Growth Factor Receptor Epitopes Targeted by Panitumumab and Cetuximab. Neoplasia 2012, 14, 1023-1031. [CrossRef] [PubMed]

114. Wang, W.; Erbe, A.K.; Hank, J.A.; Morris, Z.S.; Sondel, P.M. NK cell mediated antibody-dependent cellular cytotoxicity in cancer immunotherapy. Front. Immunol. 2015, 6. [CrossRef] [PubMed]

115. Clynes, R.A.; Towers, T.L.; Presta, L.G.; Ravetch, J.V. Inhibitory Fc receptors modulate in vivo cytoxicity against tumor targets. Nat. Med. 2000, 6, 443-446. [PubMed]

116. Weng, A.; Thakur, M.; von Mallinckrodt, B.; Beceren-Braun, F.; Gilabert-Oriol, R.; Wiesner, B.; Eichhorst, J.; Böttger, S.; Melzig, M.F.; Fuchs, H. Saponins modulate the intracellular trafficking of protein toxins. J. Control. Release 2012, 164, 74-86. [CrossRef] [PubMed]

117. Heisler, I.; Sutherland, M.; Bachran, C.; Hebestreit, P.; Schnitger, A.; Melzig, M.F.; Fuchs, H. Combined application of saponin and chimeric toxins drastically enhances the targeted cytotoxicity on tumor cells. J. Control. Release 2005, 106, 123-137. [CrossRef] [PubMed]

118. Stirpe, F.; Williams, D.G.; Onyon, L.J.; Legg, R.F.; Stevens, W.A. Dianthins, ribosome-damaging proteins with anti-viral properties from Dianthus caryophyllus L. (carnation). Biochem. J. 1981, 195, 399-405. [CrossRef] [PubMed]

119. Humphrey, P.A.; Wong, A.J.; Vogelstein, B.; Zalutsky, M.R.; Fuller, G.N.; Archer, G.E.; Friedman, H.S.; Kwatra, M.M.; Bigner, S.H.; Bigner, D.D. Anti-synthetic peptide antibody reacting at the fusion junction of deletion-mutant epidermal growth factor receptors in human glioblastoma. Proc. Natl. Acad. Sci. USA 1990, 87, 4207-4211. [CrossRef] [PubMed]

120. Nagane, M.; Coufal, F.; Lin, H.; Bögler, O.; Cavenee, W.K.; Huang, H.-J.S. A Common Mutant Epidermal Growth Factor Receptor Confers Enhanced Tumorigenicity on Human Glioblastoma Cells by Increasing Proliferation and Reducing Apoptosis. Cancer Res. 1996, 56, 5079-5086. [PubMed]

121. Huang, H.-J.S.; Nagane, M.; Klingbeil, C.K.; Lin, H.; Nishikawa, R.; Ji, X.-D.; Huang, C.-M.; Gill, G.N.; Wiley, H.S.; Cavenee, W.K. The Enhanced Tumorigenic Activity of a Mutant Epidermal Growth Factor Receptor Common in Human Cancers Is Mediated by Threshold Levels of Constitutive Tyrosine Phosphorylation and Unattenuated Signaling. J. Biol. Chem. 1997, 272, 2927-2935. [CrossRef] [PubMed]

122. Gan, H.K.; Kaye, A.H.; Luwor, R.B. The EGFRvIII variant in glioblastoma multiforme. J. Clin. Neurosci. 2009, 16, 748-754. [CrossRef] [PubMed] 
123. Ji, H.; Zhao, X.; Yuza, Y.; Shimamura, T.; Li, D.; Protopopov, A.; Jung, B.L.; McNamara, K.; Xia, H.; Glatt, K.A.; et al. Epidermal growth factor receptor variant III mutations in lung tumorigenesis and sensitivity to tyrosine kinase inhibitors. Proc. Natl. Acad. Sci. USA 2006, 103, 7817-7822. [CrossRef] [PubMed]

124. Khattri, A.; Zuo, Z.; Brägelmann, J.; Keck, M.K.; El Dinali, M.; Brown, C.D.; Stricker, T.; Munagala, A.; Cohen, E.E.W.; Lingen, M.W.; et al. Rare occurrence of EGFRvIII deletion in head and neck squamous cell carcinoma. Oral Oncol. 2015, 51, 53-58. [CrossRef] [PubMed]

125. Rae, J.M.; Scheys, J.O.; Clark, K.M.; Chadwick, R.B.; Kiefer, M.C.; Lippman, M.E. EGFR and EGFRvIII expression in primary breast cancer and cell lines. Breast Cancer Res. Treat. 2004, 87, 87-95. [CrossRef] [PubMed]

126. Grossman, S.A.; Batara, J.F. Current management of glioblastoma multiforme. Semin. Oncol. 2004, 31, 635-644. [CrossRef] [PubMed]

127. Shinojima, N.; Tada, K.; Shiraishi, S.; Kamiryo, T.; Kochi, M.; Nakamura, H.; Makino, K.; Saya, H.; Hirano, H.; Kuratsu, J.-I.; et al. Prognostic Value of Epidermal Growth Factor Receptor in Patients with Glioblastoma Multiforme. Cancer Res. 2003, 63, 6962-6970. [PubMed]

128. Bigner, S.H.; Humphrey, P.A.; Wong, A.J.; Vogelstein, B.; Mark, J.; Friedman, H.S.; Bigner, D.D. Characterization of the Epidermal Growth Factor Receptor in Human Glioma Cell Lines and Xenografts. Cancer Res. 1990, 50, 8017-8022. [PubMed]

129. Archer, G.E.; Sampson, J.H.; Lorimer, I.A.; McLendon, R.E.; Kuan, C.T.; Friedman, A.H.; Friedman, H.S.; Pastan, I.H.; Bigner, D.D. Regional treatment of epidermal growth factor receptor vIII-expressing neoplastic meningitis with a single-chain immunotoxin, MR-1. Clin. Cancer Res. 1999, 5, 2646-2652. [PubMed]

130. Beers, R.; Chowdhury, P.; Bigner, D.; Pastan, I. Immunotoxins with increased activity against epidermal growth factor receptor vIII-expressing cells produced by antibody phage display. Clin. Cancer Res. 2000, 6, 2835-2843. [PubMed]

131. Kuan, C.T.; Wikstrand, C.J.; Archer, G.; Beers, R.; Pastan, I.; Zalutsky, M.R.; Bigner, D.D. Increased binding affinity enhances targeting of glioma xenografts by EGFRvIII-specific scFv. Int. J. Cancer 2000, 88, 962-969. [CrossRef]

132. Bobo, R.H.; Laske, D.W.; Akbasak, A.; Morrison, P.F.; Dedrick, R.L.; Oldfield, E.H. Convection-enhanced delivery of macromolecules in the brain. Proc. Natl. Acad. Sci. USA 1994, 91, 2076-2080. [CrossRef] [PubMed]

133. Ding, D.; Kanaly, C.W.; Bigner, D.D.; Cummings, T.J.; Herndon, J.E.; Pastan, I.; Raghavan, R.; Sampson, J.H. Convection-enhanced delivery of free gadolinium with the recombinant immunotoxin MR1-1. J. Neuro-Oncol. 2009, 98, 1-7. [CrossRef] [PubMed]

134. Chandramohan, V.; Bao, X.; Keir, S.T.; Pegram, C.N.; Szafranski, S.E.; Piao, H.; Wikstrand, C.J.; McLendon, R.E.; Kuan, C.-T.; Pastan, I.H.; et al. Construction of an Immunotoxin, D2C7-(scdsFv)-PE38KDEL, Targeting EGFRwt and EGFRvIII for Brain Tumor Therapy. Clin. Cancer Res. 2013, 19, 4717-4727. [CrossRef] [PubMed]

135. Bao, X.; Chandramohan, V.; Reynolds, R.P.; Norton, J.N.; Wetsel, W.C.; Rodriguiz, R.M.; Aryal, D.K.; McLendon, R.E.; Levin, E.D.; Petry, N.A.; et al. Preclinical toxicity evaluation of a novel immunotoxin, D2C7-(scdsFv)-PE38KDEL, administered via intracerebral convection-enhanced delivery in rats. Investig. New Drugs 2016, 34, 149-158. [CrossRef] [PubMed]

136. Luwor, R.B.; Johns, T.G.; Murone, C.; Huang, H.-J.S.; Cavenee, W.K.; Ritter, G.; Old, L.J.; Burgess, A.W.; Scott, A.M. Monoclonal Antibody 806 Inhibits the Growth of Tumor Xenografts Expressing Either the de2-7 or Amplified Epidermal Growth Factor Receptor (EGFR) but not Wild-Type EGFR. Cancer Res. 2001, 61, 5355-5361. [PubMed]

137. Johns, T.G.; Stockert, E.; Ritter, G.; Jungbluth, A.A.; Huang, H.J.; Cavenee, W.K.; Smyth, F.E.; Hall, C.M.; Watson, N.; Nice, E.C.; et al. Novel monoclonal antibody specific for the de2-7 epidermal growth factor receptor (EGFR) that also recognizes the EGFR expressed in cells containing amplification of the EGFR gene. Int. J. Cancer 2002, 98, 398-408. [CrossRef] [PubMed]

138. Johns, T.G.; Adams, T.E.; Cochran, J.R.; Hall, N.E.; Hoyne, P.A.; Olsen, M.J.; Kim, Y.-S.; Rothacker, J.; Nice, E.C.; Walker, F.; et al. Identification of the Epitope for the Epidermal Growth Factor Receptor-specific Monoclonal Antibody 806 Reveals That It Preferentially Recognizes an Untethered Form of the Receptor. J. Biol. Chem. 2004, 279, 30375-30384. [CrossRef] [PubMed] 
139. Garrett, T.P.J.; Burgess, A.W.; Gan, H.K.; Luwor, R.B.; Cartwright, G.; Walker, F.; Orchard, S.G.; Clayton, A.H.A.; Nice, E.C.; Rothacker, J.; et al. Antibodies specifically targeting a locally misfolded region of tumor associated EGFR. Proc. Natl. Acad. Sci. USA 2009, 106, 5082-5087. [CrossRef] [PubMed]

140. Scott, A.M.; Lee, F.-T.; Tebbutt, N.; Herbertson, R.; Gill, S.S.; Liu, Z.; Skrinos, E.; Murone, C.; Saunder, T.H.; Chappell, B.; et al. A phase I clinical trial with monoclonal antibody ch806 targeting transitional state and mutant epidermal growth factor receptors. Proc. Natl. Acad. Sci. USA 2007, 104, 4071-4076. [CrossRef] [PubMed]

141. Schmidt, M.; Reiser, P.; Hills, D.; Gullick, W.J.; Wels, W. Expression of an oncogenic mutant EGF receptor markedly increases the sensitivity of cells to an EGF-receptor-specific antibody-toxin. Int. J. Cancer 1998, 75, 878-884. [CrossRef]

142. Michaelis, M.; Bliss, J.; Arnold, S.C.; Hinsch, N.; Rothweiler, F.; Deubzer, H.E.; Witt, O.; Langer, K.; Doerr, H.W.; Wels, W.S.; et al. Cisplatin-Resistant Neuroblastoma Cells Express Enhanced Levels of Epidermal Growth Factor Receptor (EGFR) and Are Sensitive to Treatment with EGFR-Specific Toxins. Clin. Cancer Res. 2008, 14, 6531-6537. [CrossRef] [PubMed]

143. Spyridonidis, A.; Schmidt, M.; Bernhardt, W.; Papadimitriou, A.; Azemar, M.; Wels, W.; Groner, B.; Henschler, R. Purging of Mammary Carcinoma Cells During Ex Vivo Culture of CD34+ Hematopoietic Progenitor Cells With Recombinant Immunotoxins. Blood 1998, 91, 1820-1827. [PubMed]

144. Schmidt, M.; Maurer-Gebhard, M.; Groner, B.; Köhler, G.; Brochmann-Santos, G.; Wels, W. Suppression of metastasis formation by a recombinant single chain antibody-toxin targeted to full-length and oncogenic variant EGF receptors. Oncogene 1999, 18, 1711-1721. [CrossRef] [PubMed]

145. Berg, K.; Weyergang, A.; Prasmickaite, L.; Bonsted, A.; Høgset, A.; Strand, M.-T.R.; Wagner, E.; Selbo, P.K. Photochemical Internalization (PCI): A Technology for Drug Delivery. In Photodynamic Therapy: Methods and Protocols; Gomer, J.C., Ed.; Humana Press: Totowa, NJ, USA, 2010; pp. 133-145.

146. Weyergang, A.; Selbo, P.K.; Berg, K. Photochemically stimulated drug delivery increases the cytotoxicity and specificity of EGF-saporin. J. Control. Release 2006, 111, 165-173. [CrossRef] [PubMed]

147. Yip, W.L.; Weyergang, A.; Berg, K.; Tønnesen, H.H.; Selbo, P.K. Targeted Delivery and Enhanced Cytotoxicity of Cetuximab-Saporin by Photochemical Internalization in EGFR-Positive Cancer Cells. Mol. Pharm. 2007, 4, 241-251. [CrossRef] [PubMed]

148. Selbo, P.K.; Rosenblum, M.G.; Cheung, L.H.; Zhang, W.; Berg, K. Multi-Modality Therapeutics with Potent Anti-Tumor Effects: Photochemical Internalization Enhances Delivery of the Fusion Toxin scFvMEL/rGel. PLoS ONE 2009, 4, e6691. [CrossRef] [PubMed]

149. Weyergang, A.; Selbo, P.K.; Berstad, M.E.B.; Bostad, M.; Berg, K. Photochemical internalization of tumor-targeted protein toxins. Lasers Surg. Med. 2011, 43, 721-733. [CrossRef] [PubMed] 